\title{
Octa-O-Methoxy Resorcin [4] Arene Amberlite XAD-4 Polymeric Chelating Resin for Solid Phase Extraction, Preconcentration, Separation and Trace Determination of $\mathrm{Ni}(\mathrm{II}), \mathrm{Cu}(\mathrm{II}), \mathrm{Zn}(\mathrm{II})$ and $\mathrm{Cd}(\mathrm{II}) \mathrm{Ions}$
}

\author{
Disha J. Vyas, Bharat A. Makwana, Keyur D. Bhatt, Vinod K. Jain* \\ Department of Chemistry, School of Sciences, Gujarat University, Ahmedabad, India \\ Email: *drvkjain@hotmail.com
}

Received March 22, 2013; revised April 25, 2013; accepted May 1, 2013

Copyright (C) 2013 Disha J. Vyas et al. This is an open access article distributed under the Creative Commons Attribution License, which permits unrestricted use, distribution, and reproduction in any medium, provided the original work is properly cited.

\begin{abstract}
Synthetic resin, Amberlite XAD-4 was linked covalently with the third generation supramolecule, octa- $O$-methoxy resorcin [4] arene through $-\mathrm{N}=\mathrm{N}$ - group to form chelating resin, which has been characterized and effectively used for the separation and preconcentration of metal ions such as $\mathrm{Ni}(\mathrm{II}), \mathrm{Cu}(\mathrm{II}), \mathrm{Zn}(\mathrm{II})$ and $\mathrm{Cd}(\mathrm{II})$. Critical parameters such as $\mathrm{pH}$, flow rate, sorption capacity, breakthrough studies, distribution coefficient, preconcentration factor, concentration of eluting agents responsible for quantitative extraction of metal ions were optimized. The synthesized resin showed good binding affinity towards $\mathrm{Ni}(\mathrm{II}), \mathrm{Cu}(\mathrm{II}), \mathrm{Zn}(\mathrm{II})$ and $\mathrm{Cd}(\mathrm{II})$ under selective $\mathrm{pH}$ conditions. Good breakthrough capacity and fast exchange kinetics of the resin lead to effective separation of metal ions from their binary and ternary mixture by column method on the basis of $\mathrm{pH}$ and eluting agents. The resin could be reused for about $8-10$ cycles. The proposed method having the analytical data with the relative standard deviation (RSD) $<2 \%$ and with recoveries of analytes higher than $98 \%$, reflects upon the reproducibility and reliability of the method which has been successfully applied in the separation and determination of $\mathrm{Ni}(\mathrm{II}), \mathrm{Cu}(\mathrm{II}), \mathrm{Zn}(\mathrm{II})$ and $\mathrm{Cd}(\mathrm{II})$ ions in synthetic, natural and ground water samples.
\end{abstract}

Keywords: Separation; Preconcentration; Amberlite XAD-4; Octa-O-Methoxy Resorcin [4] Arene; Solid Phase Extraction

\section{Introduction}

It is well recognized that several trace elements are essential constituents of enzymes and play a vital role in human metabolism and primarily supplied through diet and drinking water. However, beyond the essential range, deficiency and toxic effects are observed [1]. Considering biological research, the role of some trace and ultratrace elements in the body is very important and has diverse functions. Some of the trace elements are essential to life while others are toxic even at low concentrations [2-6]. Many metals listed as environmental hazards are essential dietary trace elements required for normal growth and development of animals and human beings. These metals are essential to human life within permissible limits. Toxicity of metal ions such as nickel, copper, zinc and cadmium in human beings is as follows:

\footnotetext{
${ }^{*}$ Corresponding author.
}

Nickel: Nickel plays important roles in the biology of microorganisms and plants [7-12]. Nickel sulfide fume as well as dust is believed to be carcinogenic, various other nickel compounds may be as well [7-12].

Copper: Copper is an economically important element which is found only in trace quantities in the earth's crust. It is required as a trace nutrient for both plants and animals, but excessive amounts are toxic [13].

Zinc: Men and many animals exhibit considerable tolerance to high zinc intakes. This tolerance is dependent on the nature of diet, and its $\mathrm{Ca}, \mathrm{Cu}, \mathrm{Fe}$ and $\mathrm{Cd}$ contents with which zinc interacts in the process of adsorption and utilization. Symptoms of zinc toxicity in humans include vomiting, electrolyte imbalance, dehydration, abdominal pain, nausea, dizziness etc. [7-12].

Cadmium: Cadmium is non-essential and toxic to human and animal systems [14]. Small quantities of cadmium cause adverse changes in the arteries of human 
kidneys and liver [15]. Teratogenic properties have been shown [16] whereas carcinogenic properties are suspected [17-19].

In this regard, evaluation of trace metals in the environmental samples including natural water has been continuously performed to designate the level of pollution which creates health problems [20,21]. Several analytical techniques have been used for the determination of heavy metal ions in the real samples which include Inductively coupled plasma-atomic emission spectrophotometer (ICPAES) [22], flame atomic absorption spectrometry (FAAS) [23] etc. These techniques are both widely and routinely used for the determination of trace amounts of heavy metal ions. However, the direct determination of heavy metal ions at trace levels is limited not only due to insufficient sensitivity, but also by matrix interference [24,25].

In order to overcome these difficulties, preliminary separation and preconcentration of trace elements from the matrix are frequently used techniques to improve the detection limit and the selectivity [26]. Separation technique, in general, deal with the separation of components of mixtures to enhance the purity of substances while in preconcentration technique, one of the analytes or species have been selectively retained on a solid phase and then eluted with an appropriate eluent, and detected and quantified by an appropriate detection technique [27].

Different separation and preconcentration techniques using solid phase extraction (SPE) [28], co-precipitation [29] solvent extraction [30], membrane filtration [31], cloud point extraction [32,33], flotation [34], electrochemical decomposition [35] ion exchange etc. have been developed for the trace metal ion determination. Among these solid-phase extraction technique have been widely used because of its various advantages over other methods, such as higher preconcentration factor, lesser waste generation, lower matrix effect, use of less toxic solvents, saving of time and cost, easy regenerability of a solid phase and thereby more reusability [36-39].

Various SPE materials which have been used for the preconcentration of trace metal ions as their chelates include, activated silica gel [40,41], carbon [42-45], polyurethane foam [46] microcrystalline naphthalene [47], $\mathrm{C}_{18}$ cartridges [48], Chelex-100 [49], Alumina [50], functionalized polyurethane foam [51], modified silica [52, 53], sulfur powder [54] and Amberlite XAD resins [5561]. Amberlite XAD (styrene-divinyl benzene copolymer) resins, as the copolymer backbone for the immobilization of chelating ligands, have some physical superiority, such as porosity, uniform pore size distribution, high surface area, and chemical stability toward acids, bases, and oxidizing agents, as compared to other resins [62-65]. Either the adsorption of chelating ligands onto these supports or the covalent coupling of chelating moiety has been used to design polymeric chelating resins, which are versatile, durable, have good loading capacity towards metals, exhibit enhanced hydrophilicity and flexible working conditions. That is why the reaction of Amberlite XAD resin with suitable chelating agents is very popular for separation and preconcentration [66-71].

Calix [4] resorcinarenes possess good capability to form a variety of complexes with organic/inorganic ions, neutral molecules, transition metal complexes and organometallics [72] for the simple reason that they can be functionalized at the upper rim or at C-methyl position or at hydroxyl groups at extra-annular position, enabling them to be used as multifunctional receptors [73]. Literature reveals only few reports on the extraction of metal ions using calyx [4] resorcinarene and its derivatives [74-80]. As far as work on polymer supported calyx [4] resorcinarenes is concerned, Merdivan et al. [31,81, 82] have reported the use of calyx [4] resorcinarene impregnated on Amberlite XAD for separation and preconcentration of rare earths.

Here, the use octa-O-methoxy resorcin [4] arene Amberlite XAD-4 chelating resin for extraction, preconcentration and sequential separation of metal ions such as $\mathrm{Ni}(\mathrm{II}), \mathrm{Cu}(\mathrm{II}), \mathrm{Zn}(\mathrm{II})$ and $\mathrm{Cd}(\mathrm{II})$ in a column prior to their determination by Spectrophotometry/FAAS/ICP-AES is described. Different factors influencing the separation and preconcentration of these metal ions, such as $\mathrm{pH}$, concentration of eluting agents, flow rate, total sorption capacity, exchange kinetics, preconcentration factor, distribution coefficient, breakthrough capacity, resin stability, effect of electrolytes, and associated metal ions have been investigated. The newly developed method has also been applied for the determination of $\mathrm{Ni}(\mathrm{II}), \mathrm{Cu}(\mathrm{II}), \mathrm{Zn}$ (II) and $\mathrm{Cd}(\mathrm{II})$ metal ions from industrial affluent, natural river and ground water samples of Ahmedabad (Gujarat) City.

\section{Experimental}

\subsection{Reagents}

All the chemicals used in this work were of analytical grade purchased from Sigma-Aldrich and Merck. Amberlite XAD-4 with surface area $750 \mathrm{~m}^{2} \cdot \mathrm{g}^{-1}$, pore diameter $50 \AA$ and bead size 20 - 50 mesh was procured from Fluka. All aqueous solutions were prepared with quartz distilled deionized water. Glassware were soaked in 5\% $\mathrm{HNO}_{3}$ overnight and cleaned with double distilled deionized water before use. The $\mathrm{pH}$ was adjusted with the following buffer solutions: $\mathrm{PO}_{4}^{-3} / \mathrm{HPO}_{4}^{-2}$ buffer for $\mathrm{pH}$ 2.0 and 3.0; $\mathrm{CH}_{3} \mathrm{COO}^{-1} / \mathrm{CH}_{3} \mathrm{COOH}$ buffer for $\mathrm{pH} 4.0$ to $6.0 ; \mathrm{HPO}_{4}^{-2} / \mathrm{H}_{2} \mathrm{PO}_{4}^{-1}$ buffers for $\mathrm{pH} 7.0$ and 7.5 ; $\mathrm{NH}_{3} / \mathrm{NH}_{4}^{+}$buffers of $\mathrm{pH} 8$ to 10 .

Standard stock solutions $\left(1000 \mu \mathrm{g} \cdot \mathrm{mL}^{-1}\right)$ of $\mathrm{Ni}(\mathrm{II})$, $\mathrm{Cu}(\mathrm{II}), \mathrm{Zn}(\mathrm{II})$, and $\mathrm{Cd}(\mathrm{II})$ were prepared by dissolving $0.4045 \mathrm{gm} \mathrm{NiCl} 2 \cdot 6 \mathrm{H}_{2} \mathrm{O} ; 0.384 \mathrm{gm} \mathrm{Cu}\left(\mathrm{NO}_{3}\right)_{2} \cdot 3 \mathrm{H}_{2} \mathrm{O}$; 
$0.4541 \mathrm{gm} \mathrm{Zn}\left(\mathrm{NO}_{3}\right)_{2} \cdot 6 \mathrm{H}_{2} \mathrm{O} ; 0.2744 \mathrm{gm} \mathrm{Cd}\left(\mathrm{NO}_{3}\right)_{2} \cdot 4 \mathrm{H}_{2} \mathrm{O}$ in $1 \mathrm{~mL}$ concentrated $\mathrm{HNO}_{3}$ and dilute upto $100 \mathrm{~mL}$ with water in volumetric flask.

\subsection{Instruments}

Spectral measurements were carried out using JASCO $570 \mathrm{UV}$-vis spectrophotometer using $10 \mathrm{~mm}$ quartz cells. The metal content determinations were carried out using (FAAS) NOVAA $400 \mathrm{p}$ model with hollow cathode lamps, equipped with an air-acetylene flame without background correction and the operating conditions adjusted were carried out according to the standard guidelines of the manufacturers. When metal ion concentration was too law for its direct determination, inductively coupled plasma-atomic absorption spectrometer (ICP-AES) JY 2000-2 was used. The flow of the liquid through the column was controlled by Miclins Peristaltic pump PP10 EX. Elico digital pH-meter, model L1 614 equipped with a combined $\mathrm{pH}$ electrode was employed for measuring $\mathrm{pH}$.

The water samples from Sabarmati River, ground water from the University area and Vatva industrial zone of Ahmedabad city were collected.

\subsection{Synthesis}

Octa-O-methoxy resorcin [4] arene, the third generation supramolecule was synthesized by the acid catalyzed condensation reaction of 1,3 dimethoxy benzene and p-hydroxy benzaldehyde as reported earlier [83]. Octa$O$-methoxy resorcin [4] arene covalently linked with Amberlite XAD-4 through azo $(-\mathrm{N}=\mathrm{N}-)$ linkage as per Scheme 1.

\section{Synthesis of Amberlite XAD-4-Octa-O-Methoxy Resorcin [4] Arene}

The nitration of Amberlite XAD-4 beads, the reduction of the nitrated resin and the subsequent diazotization of the amino resin was carried out by the procedure reported earlier for Amberlite XAD-2 [84]. The resulting diazotized resin was allowed to react with octa- $O$-methoxy resorcin [4] arene (1.0 g dissolved in $50 \mathrm{~mL}$ of $10 \%$ $\mathrm{NaOH})$ at $0^{\circ} \mathrm{C}-5^{\circ} \mathrm{C}$ for $48 \mathrm{~h}$. The dark brown coloured beads were filtered, successively washed with double distilled water and finally dried for further studies.

\subsection{General Batch Method}

Octa-O-methoxy resorcin [4] arene Amberlite XAD-4 polymeric chelating resin (1.0 gm) was added into a glass stoppered bottle containing $100 \mathrm{~mL}$ of each $\mathrm{Ni}(\mathrm{II}) / \mathrm{Cu}(\mathrm{II}) /$ $\mathrm{Zn}(\mathrm{II}) / \mathrm{Cd}(\mathrm{II})$ solutions atan optimum $\mathrm{pH}$ conditions and the bottle was shaken for about 30 minutes. The resin was filtered and washed with double distilled water. The amount of metal ions extracted by resin was determined by using suitable eluting agents like $\mathrm{HCl}$ or $\mathrm{HNO}_{3}$ by

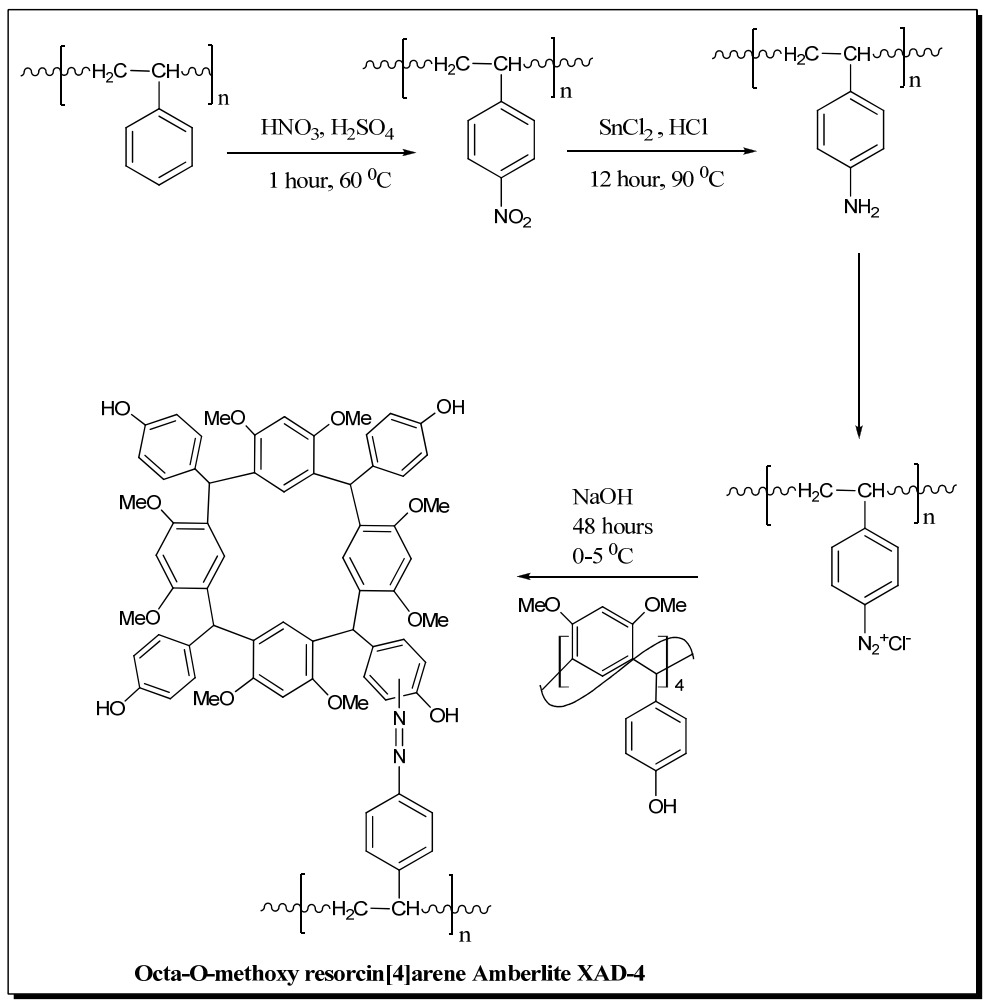

Scheme 1. Synthesis of octa- $O$-methoxy resorcin [4] arene supported Amberlite XAD-4 polymeric chelating resin. 
spectrophotometry/FAAS/ICP-AES.

\subsection{Generalcolumn Method}

1.0 gm of octa- $O$-methoxy resorcin [4] arene Amberlite $\mathrm{XAD}-4$ polymeric chelating resin was added to the mixture of $\mathrm{CH}_{3} \mathrm{OH}: \mathrm{H}_{2} \mathrm{O}(1: 1)$ and poured onto the $(10 \mathrm{~cm}$ long, $1 \mathrm{~cm}$ inner diameter) glass column equipped with a stopcock and a porous disk. The resin was then washed with deionized water and conditioned with $15-20 \mathrm{~mL}$ buffer solution of desired $\mathrm{pH}$ prior to the passage of suitable aliquot of the sample solution containing metal ions ( $\mathrm{Ni}(\mathrm{II}), \mathrm{Cu}(\mathrm{II}), \mathrm{Zn}(\mathrm{II})$ and $\mathrm{Cd}(\mathrm{II})$ ) at an optimum flow rate. The amount bound metal ions stripped with suitable eluting agents was determined by spectrophotometry/FAAS/ICP-AES.

\section{Results and Discussion}

\subsection{Spectral Interpretation of Synthesized Octa-O-Methoxy Resorcine [4] Arene Amberlite XAD-4 Polymeric Chelating Resin}

The octa-O-methoxy resorcin [4] arene Amberlite XAD4 polymeric cheltaing resin was characterized by elemental analysis, FT-IR and mass difference. The nitrogen content in Amino-XAD-4 was found to be $2.73 \%$ higher than Nitro-XAD-4, confirms the successful reduction of Nitro-XAD-4 resin. The FT-IR spectra of $\mathrm{NO}_{2}-\mathrm{XAD}-4$, $\mathrm{NH}_{2}$-XAD-4 and octa-O-methoxy resorcin [4] arene Amberlite XAD-4 chelating resin, are given in Figure 1. Asymm (N-O) and symm (N-O) stretching bands of the $\mathrm{NO}_{2}$-XAD-4 were observed at 1540 and $1325 \mathrm{~cm}^{-1}$, respectively. The N-H stretching vibrations of $\mathrm{NH}_{2}-\mathrm{XAD}-4$ were identified with the bands at 3400 and 1625. The conspicuous band of $-\mathrm{N}=\mathrm{N}$ - at $1470 \mathrm{~cm}^{-1}$ confirms the successful formation of octa- $O$-methoxy resorcin [4] arene Amberlite XAD-4 chelating resin through $-\mathrm{N}=\mathrm{N}$ linkage. Apart from this, the loading of octa- $O$-methoxy resorcin [4] arene $\left(0.61 \mathrm{mmole} \cdot \mathrm{g}^{-1}\right)$ on synthetic XAD-4 resin was calculated by mass difference of dried resin, which also confirms nitration, reduction and coupling of diazotized Amberlite XAD-4 resin with octa-O-methoxy resorcin [4] arene.

\subsection{Parameters Optimized for Separation and Preconcentration of $\mathrm{Ni}(\mathrm{II}), \mathrm{Cu}(\mathrm{II}), \mathrm{Zn}$ (II) and $\mathrm{Cd}(\mathrm{II})$}

\subsubsection{Effect of pH on Quantitative Absorption}

The $\mathrm{pH}$ of the solutions plays an important role on ex- traction of metal ions. The influence of $\mathrm{pH}$ of the aqueous solution containing $5 \mu \mathrm{g} \cdot \mathrm{mL}^{-1}$ of each $\mathrm{Ni}(\mathrm{II}), \mathrm{Cu}(\mathrm{II})$, $\mathrm{Zn}(\mathrm{II})$, and $\mathrm{Cd}(\mathrm{II})$ on $1.0 \mathrm{gm}$ of octa- $\mathrm{O}$-methoxy resorcin [4] arene Amberlite XAD-4 polymeric chelating resin was investigated using the batch method. A $100 \mathrm{~mL}$ aqueous solution of each metal ion with buffer solution of desired $\mathrm{pH}$ was placed in glass stoppered bottles and stirred slowly for 1 hour. The $\mathrm{pH}$ for maximum sorption of $\mathrm{Ni}(\mathrm{II}), \mathrm{Cu}(\mathrm{II}), \mathrm{Zn}(\mathrm{II})$, and $\mathrm{Cd}(\mathrm{II})$ was found to be 3.5 , 5.5, 5.0 and 8.0, respectively (Table 1, Figure 2).

\subsubsection{Effect of Flow Rate on Metal Sorption}

The metal ion sorption on $1.0 \mathrm{gm}$ resin was evaluated at different flow rates $\left(0.5,1.0,1.5,2.0,2.5\right.$ etc., $\left.\mathrm{mL} \cdot \mathrm{min}^{-1}\right)$, maintained by a peristaltic pump. The rate of flow of the effluent at which $98 \%$ sorption took place is consider as the optimum flow rate for the sorption of metal ions. For $\mathrm{Ni}(\mathrm{II}), \mathrm{Cu}(\mathrm{II}), \mathrm{Zn}(\mathrm{II})$, and $\mathrm{Cd}(\mathrm{II})$, the optimum flow rate was found to be $2.5,2.0,1.5$ and $1.0 \mathrm{ml} \cdot \mathrm{min}^{-1}$, respectively (Table 1, Figure 3). The obtained flow rates for maximum sorption were employed for the subsequent analysis.

\subsubsection{Effect of Type and Concentration of Elutent on Recovery}

The choice of a suitable eluent is another important factor to obtain efficient and selective recovery of analytes. In this study, a series of experiments were performed to obtain a reasonable eluent to elute $\mathrm{Ni}(\mathrm{II}), \mathrm{Cu}(\mathrm{II})$, $\mathrm{Zn}(\mathrm{II})$, and $\mathrm{Cd}(\mathrm{II})$ ions from metal bound resin. The bound metal ions were desorbed with different concentration of eluting agents, $\left(\mathrm{HCl} / \mathrm{HNO}_{3}\right)$ and were determined by FAAS/ICP-AES. Quantitative elution was found possible with $1.5 \mathrm{~N} \mathrm{HCl}$ for $\mathrm{Ni}(\mathrm{II}), 1.0 \mathrm{~N} \mathrm{HNO}_{3}$ for $\mathrm{Cu}(\mathrm{II}), 1.0 \mathrm{~N} \mathrm{HCl}$ for $\mathrm{Zn}(\mathrm{II})$ and $0.5 \mathrm{~N} \mathrm{HNO}_{3}$ for $\mathrm{Cd}(\mathrm{II})$ (Tables 1 and 2).

\subsubsection{Sorption Capacity and Distribution Coefficients}

The batch method was used for the calculation of the sorption capacity of resin for metal ions. $1.0 \mathrm{gm}$ of resin was added to $100 \mathrm{~mL}$ of solution containing excess of metal ions $\left(100 \mathrm{~mL}, 1000 \mu \mathrm{g} \cdot \mathrm{mL}^{-1}\right)$ at their respective $\mathrm{pH}$ by shaking for $1 \mathrm{~h}$. The amount of metal ions extracted by resin was calculated from the difference in the metal ion concentration before and after sorption (Table 1). The capacity of resin for $\mathrm{Ni}(\mathrm{II}), \mathrm{Cu}(\mathrm{II}), \mathrm{Zn}$ (II), and $\mathrm{Cd}$ (II) was found to be $26,000,49,650,40,499$ and $52,310 \mu \mathrm{g} \cdot \mathrm{gm}^{-1}$, respectively.

Exchange equilibria arearticulated in terms of the distribution coefficient $K_{d}$, which is given by the ratio of the

$$
K_{d}=\frac{\text { Amount of the metal ion taken up by the resin }}{\text { Amount of the metal ion remaining in the solution }} \times \frac{\text { Volume of the solution }}{\text { Amount of resin taken }}
$$




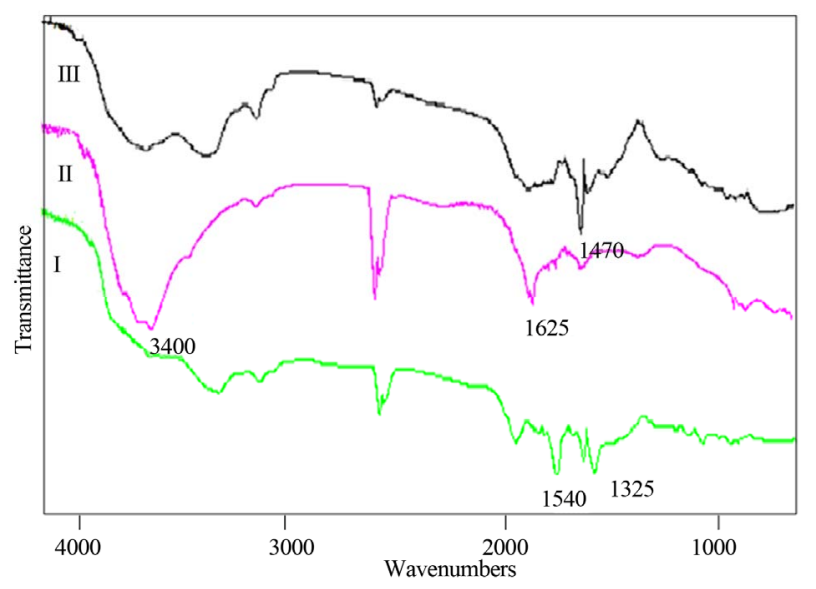

Figure 1. IR of I) $\mathrm{NO}_{2}-\mathrm{XAD}-4$ resin II $\mathrm{NH}_{2}-\mathrm{XAD}-4$ resin III octa- $O$-methoxy resorcin [4] arene Amberlite XAD-4 chelating resin.

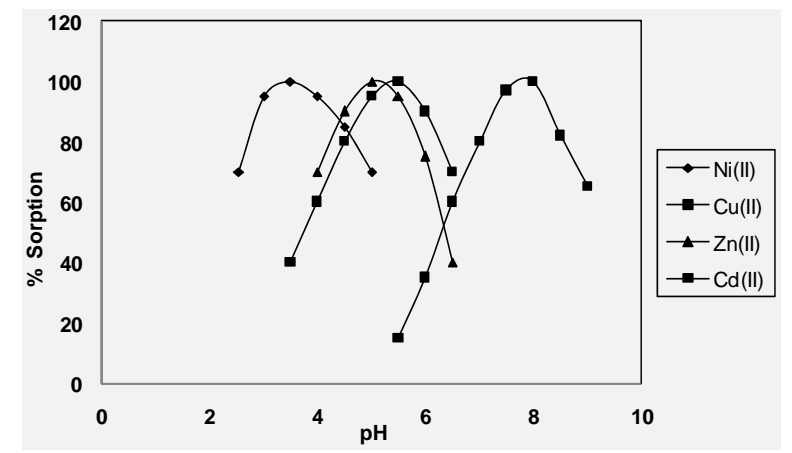

Figure 2. Effect of $\mathrm{pH}$ on the sorption of $\mathrm{Ni}(\mathrm{II}), \mathrm{Cu}(\mathrm{II})$, $\mathrm{Zn}$ (II) and Cd(II) on resin; Experimental conditions: Amount of resin in column: $1.0 \mathrm{gm}$; Amount of metal ions; $\mathrm{Ni}$ (II) $\mathrm{pH}$ : 3.5; Cu(II) pH: 5.5; Zn(II) pH: 5.0; Cd(II) pH: 8.0.

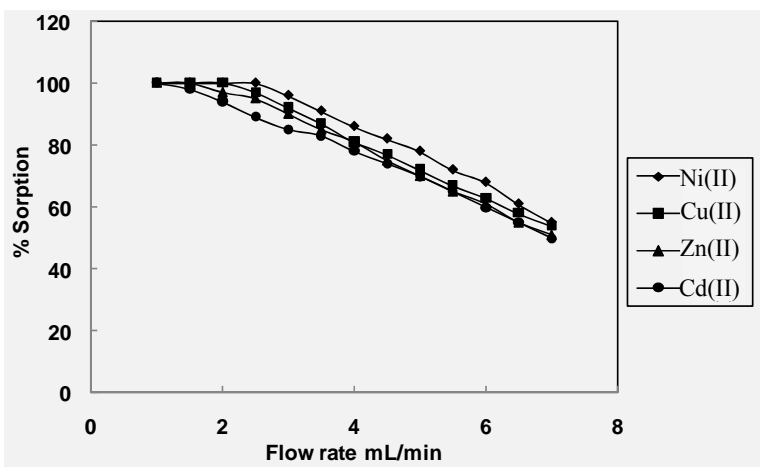

Figure 3. Effect of flow rate on the sorption of $\mathrm{Ni}(\mathrm{II}), \mathrm{Cu}(\mathrm{II})$ $\mathrm{Zn}$ (II) and Cd(II) on resin; Experimental conditions: Amount of resin: $1.0 \mathrm{gm}$; Amount of metal ions: $5 \mu \mathrm{g} \cdot \mathrm{mL}^{-1}$; $\mathrm{Ni}(\mathrm{II})$ pH: 3.5; Cu(II) pH: 5.5; Zn(II) pH: 5.0; Cd(II) pH: 8.0.

equilibrium concentrations of the same metal ion in the resin phase and in the solution.

$0.5 \mathrm{gm}$ resin was added to $100 \mathrm{~mL}$ solution containing $130,248,202,261 \mu \mathrm{g} \cdot \mathrm{mL}^{-1}$ of $\mathrm{Ni}(\mathrm{II}), \mathrm{Cu}(\mathrm{II}), \mathrm{Zn}(\mathrm{II})$ and $\mathrm{Cd}(\mathrm{II})$ at room temperature. The solution was filtered and
Table 1. Parameters optimized for sorption and desorption of $\mathrm{Ni}(\mathrm{II}), \mathrm{Cu}(\mathrm{II}), \mathrm{Zn}(\mathrm{II})$ and $\mathrm{Cd}(\mathrm{II})$ on resin.

\begin{tabular}{|c|c|c|c|c|c|}
\hline \multirow{2}{*}{ No. } & \multirow{2}{*}{ Parameters } & \multicolumn{4}{|c|}{ Resin } \\
\hline & & $\mathrm{Ni}(\mathrm{II})$ & $\mathrm{Cu}(\mathrm{II})$ & $\mathrm{Zn}(\mathrm{II})$ & $\mathrm{Cd}(\mathrm{II})$ \\
\hline 1 & pH range & 3.5 & 5.5 & 5.0 & 8.0 \\
\hline 2 & Flow rate $\left(\mathbf{m L} \cdot \mathbf{M i n}^{-1}\right)$ & 2.5 & 2.0 & 1.5 & 1.0 \\
\hline 3 & $\begin{array}{c}\text { Concentration of acid for } \\
\text { desorption }\end{array}$ & $\begin{array}{l}1.5 \mathrm{~N} \\
\mathrm{HCl}\end{array}$ & $\begin{array}{l}1.0 \mathrm{~N} \\
\mathrm{HNO}_{3}\end{array}$ & $\begin{array}{l}1.0 \mathrm{~N} \\
\mathrm{HCl}\end{array}$ & $\begin{array}{l}0.5 \mathrm{~N} \\
\mathrm{HNO}_{3}\end{array}$ \\
\hline 4 & $\begin{array}{l}\text { Total sorption capacity } \\
\left(\mu \mathrm{g} \cdot \mathrm{gm}^{-1} \text { of resin }\right)\end{array}$ & 26,000 & 49,650 & 40,499 & 52,310 \\
\hline 5 & $\begin{array}{c}\text { Distribution } \\
\text { coefficient }\left(K_{d}\right)\end{array}$ & 4333 & 7085 & 6733 & 8700 \\
\hline 6 & $\begin{array}{l}\text { Preconcentration } \\
\quad \text { factor (PF) }\end{array}$ & 105 & 108 & 95 & 112 \\
\hline 7 & $\begin{array}{l}\text { Breakthrough capacity } \\
\left(\mu \mathrm{g} \cdot \mathrm{gm}^{-1} \text { of resin }\right)\end{array}$ & 7540 & 12,909 & 10,529 & 14,123 \\
\hline 8 & Average recovery (\%) & 97 & $95-96$ & 96 & $97-98$ \\
\hline 9 & $t_{1 / 2}$ for exchange (minutes) & 7.0 & 4.0 & 5.0 & 10.0 \\
\hline 10 & $\begin{array}{l}\text { Relative standard } \\
\text { deviation }(\%)^{*}\end{array}$ & 1.5 & 1.7 & 1.8 & 1.6 \\
\hline
\end{tabular}

*Average of 10 determination.

the filtrate was subjected to FAAS/ICP-AES for determination of the metal content (Table 1). $K_{d}$ was found to be $4333,7085,6733,8700$ for $\mathrm{Ni}(\mathrm{II}), \mathrm{Cu}(\mathrm{II}), \mathrm{Zn}(\mathrm{II})$ and Cd(II) respectively.

\subsubsection{Exchange Kinetics}

To determine rate of loading of metal ions $\mathrm{Ni}(\mathrm{II}), \mathrm{Cu}(\mathrm{II})$, $\mathrm{Zn}$ (II) and $\mathrm{Cd}(\mathrm{II})$ on resin, the kinetics of sorption was studied by batch method in which 1.0 gm resin was stirred with $100 \mathrm{~mL}$ of solution containing 260, 496, 404 and $523 \mu \mathrm{g} \cdot \mathrm{mL}^{-1}$ of $\mathrm{Ni}(\mathrm{II}), \mathrm{Cu}(\mathrm{II}), \mathrm{Zn}(\mathrm{II})$ and $\mathrm{Cd}(\mathrm{II})$ respectively. An aliquot of $1.0 \mathrm{~mL}$ was withdrawn each time at apredetermined interval and analysed using FAAS. The time taken $\left(t_{1 / 2}\right)$ for the $50 \%$ sorption of $\mathrm{Ni}(\mathrm{II}), \mathrm{Cu}(\mathrm{II}), \mathrm{Zn}(\mathrm{II})$ and $\mathrm{Cd}(\mathrm{II})$ on resin, was found to be 7.0, 4.0, 5.0 and 10.0 minutes (Table 1, Figure 4) respectively, which indicates comparatively good accessibility of $\mathrm{Ni}(\mathrm{II}), \mathrm{Cu}(\mathrm{II}), \mathrm{Zn}(\mathrm{II})$ and $\mathrm{Cd}(\mathrm{II})$ towards chelating sites.

\subsubsection{Breakthrough Studies}

The capacity of the Moment when analyte starts appearing in the effluent with increased concentration is defined as the breakthrough capacity or actual working capacity. It is more significant than total sorption capacity. Breakthrough studies with $1.0 \mathrm{gm}$ of rein in the column containing $100 \mu \mathrm{g} \cdot \mathrm{mL}^{-1}$ of metal ions [Ni(II), Cu(II), Zn(II), and $\mathrm{Cd}(\mathrm{II})]$ at their optimum $\mathrm{pH}$ and flow rates was carried out. For the metal content determination, $20 \mathrm{~mL}$ aliquot was collected each time and analyzed by FAAS/ 
Table 2. Effect of concentration of eluting agents for desorption of $\mathrm{Ni}(\mathrm{II}), \mathrm{Cu}(\mathrm{II}), \mathrm{Zn}$ (II) and $\mathrm{Cd}$ (II) from resin. [Experimental conditions: resin $1.0 \mathrm{gm}$; volume of solution passed: $100 \mathrm{~mL}$; metal ions: $5 \mu \mathrm{g} \cdot \mathrm{mL}^{-1} \mathrm{Ni}(\mathrm{II}): 3.5 \mathrm{pH} ; \mathrm{Cu}(\mathrm{II}): \mathrm{pH} 5.5 ; \mathrm{Zn}(\mathrm{II}): \mathrm{pH}$ 5.0; Cd(II): pH 8.0].

\begin{tabular}{|c|c|c|c|c|c|c|c|c|}
\hline Resin & & & & & & & & \\
\hline \multirow{2}{*}{ Conc. (N) } & \multicolumn{4}{|c|}{$\mathrm{HCl}$} & \multicolumn{4}{|c|}{$\mathrm{HNO}_{3}$} \\
\hline & $\mathrm{Ni}(\mathrm{II})(\%)$ & $\mathrm{Cu}(\mathrm{II})(\%)$ & $\mathrm{Zn}(\mathrm{II})(\%)$ & Cd(II) (\%) & $\mathrm{Ni}(\mathrm{II})(\%)$ & $\mathrm{Cu}(\mathrm{II})(\%)$ & Zn(II) (\%) & $\mathrm{Cd}(\mathrm{II})(\%)$ \\
\hline 0.01 & 4.1 & 2.1 & 5.8 & 3.5 & 5.5 & 9.6 & 3.2 & 28.6 \\
\hline 0.05 & 20.1 & 3.9 & 25.4 & 9.0 & 25.7 & 38.8 & 21.3 & 66.3 \\
\hline 0.1 & 30.5 & 8.9 & 60.5 & 12.8 & 41.5 & 47.7 & 55.8 & 83.5 \\
\hline 0.5 & 50.2 & 10.5 & 75.3 & 18.5 & 60.2 & 72.5 & 70.2 & 98.7 \\
\hline 0.7 & 65.7 & 12.4 & 90.1 & 21.3 & 75.2 & 90.8 & 85.5 & 98.8 \\
\hline 1 & 85.5 & 15.1 & 98.5 & 33.5 & 88.9 & 98.5 & 95.5 & 98.8 \\
\hline 1.5 & 98.9 & 25.9 & 98.5 & 67.2 & 95.5 & 98.6 & 97.5 & 98.9 \\
\hline 2 & 98.9 & 40.6 & 98.9 & 79.8 & 98.7 & 98.9 & 97.8 & 98.9 \\
\hline
\end{tabular}

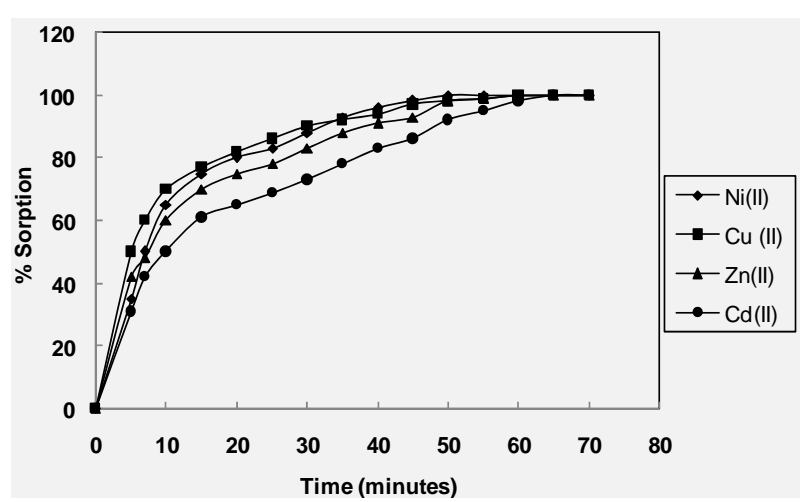

Figure 4. Exchange kinetics of $\mathrm{Ni}(\mathrm{II}), \mathrm{Cu}(\mathrm{II}), \mathrm{Zn}$ (II) and Cd(II) on theresin; Experimental conditions: Amount of resin: $1.0 \mathrm{gm}$; volume of the feed solution: $100 \mathrm{~mL}$; $\mathrm{Ni}(\mathrm{II})$ : $260 \mu \mathrm{g} \cdot \mathrm{mL}^{-1}$, pH: 3.5; Cu(II): $496 \mu \mathrm{g} \cdot \mathrm{mL}^{-1}$, pH: 5.5; $\mathrm{Zn}(\mathrm{II}):$ $404 \mu \mathrm{g} \cdot \mathrm{mL}^{-1}$, pH: 5.0; Cd(II): $523 \mu \mathrm{g} \cdot \mathrm{mL}^{-1}$, pH: 8.0.

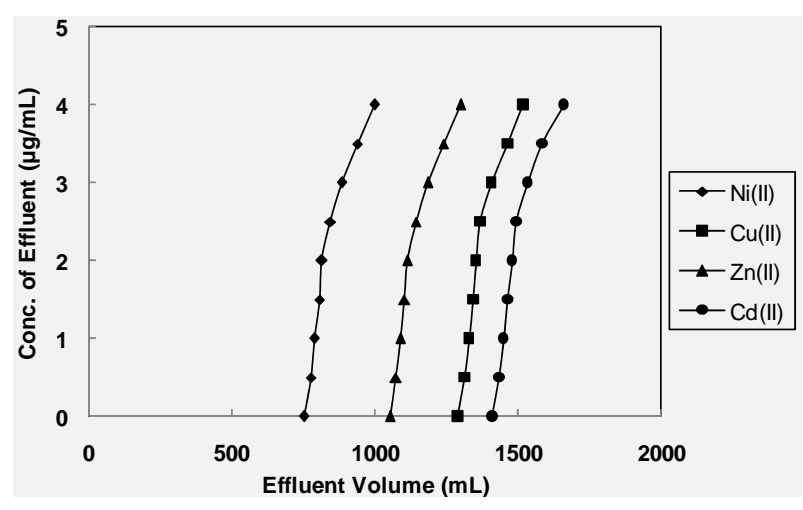

Figure 5. Breakthrough curve for $\mathrm{Ni}(\mathrm{II}), \mathrm{Cu}(\mathrm{II}), \mathrm{Zn}$ (II) and Cd(II) on the resin; Experimental conditions: Amount of resin: $1.0 \mathrm{gm}$; concentration of the metal ion solution passed: $100 \mu \mathrm{g} \cdot \mathrm{mL}^{-1}$; Ni(II): $3.5 \mathrm{pH}$; Cu(II): $5.5 \mathrm{pH}$; Zn(II): $5.0 \mathrm{pH}$; Cd(II): 8.0 pH.
ICP-AES (Figure 5). Breakthrough capacities were found to be $7540,12,909,10,529$ and $14,123 \mu \mathrm{g} \cdot \mathrm{gm}^{-1}$ for $\mathrm{Ni}(\mathrm{II})$, $\mathrm{Cu}(\mathrm{II}), \mathrm{Zn}(\mathrm{II})$, and $\mathrm{Cd}(\mathrm{II})$, respectively (Table 1).

\subsubsection{Preconcentration of $\mathrm{Ni}(\mathrm{II}), \mathrm{Cu}(\mathrm{II}), \mathrm{Zn}(\mathrm{II})$, and Cd(II)}

The purpose of preconcentration study is to transfer metal ions from the large volume of sample solution to the relatively small volume. Preconcentration of trace metal ions have been widely used in order to increase the sensitivity of the analytical methods. To study the precocnetration factor, $1000 \mathrm{~mL}$ solutions containing 8 $\mu \mathrm{g} \cdot \mathrm{L}^{-1}$ of each $\mathrm{Ni}(\mathrm{II}), \mathrm{Cu}(\mathrm{II}), \mathrm{Zn}(\mathrm{II})$ and $\mathrm{Cd}(\mathrm{II})$ at $\mathrm{pH} 3.5$, $5.5,5.0,8.0$ respectively, were passed through the column containing $1.0 \mathrm{gm}$ resin. Metal content in the striped solution were determined by ICP-AES.

$$
\mathrm{PF}=\frac{\text { Concentration of metal in stripping solution }}{\text { Initial concentration of metal in feed solution }}
$$

The preconcentrating ability of resin was evaluated from the elution profile of metal ions by plotting the concentration of effluents as a function of the volume of stripping solutions: $9.5 \mathrm{~mL}, 1.5 \mathrm{~N} \mathrm{HCl}$ for $\mathrm{Ni}(\mathrm{II}) ; 9.2 \mathrm{~mL}$, $1.0 \mathrm{~N} \mathrm{HNO}_{3}$ for $\mathrm{Cu}(\mathrm{II}) ; 10.5 \mathrm{~mL}, 1.0 \mathrm{~N} \mathrm{HCl}$ for $\mathrm{Zn}(\mathrm{II})$ and $9.0 \mathrm{~mL}, 0.5 \mathrm{~N} \mathrm{HNO}_{3}$ for $\mathrm{Cd}(\mathrm{II})$. Under the optimum experimental conditions, the preconcentration factors were found to be 105, 95, 108 and 112 for $\mathrm{Ni}(\mathrm{II}), \mathrm{Cu}(\mathrm{II}), \mathrm{Zn}$ (II) and $\mathrm{Cd}(\mathrm{II})$ with more than $96 \%$ recovery (Tables $\mathbf{1}$ and $\mathbf{3}$, Figure 6).

\subsubsection{Stability and Reusability of the Resin}

The reusability and applicability of the synthesized resin was examined after several loading and elution cycles. It 
Table 3. Preconcentration factors for the sorption of $\mathrm{Ni}(\mathrm{II}), \mathrm{Cu}(\mathrm{II}), \mathrm{Zn}$ (II) and $\mathrm{Cd}(\mathrm{II})$ on resin. [Experimental conditions: resin: $1.0 \mathrm{gm}$; $\mathrm{Ni}(\mathrm{II})$ : $\mathrm{pH} 3.5$; elution by $1.5 \mathrm{~N} \mathrm{HCl}$; $\mathrm{Cu}(\mathrm{II})$ : pH 5.5; elution by $1.0 \mathrm{~N} \mathrm{HNO}$; $\mathrm{Zn}(\mathrm{II})$ : pH 5 ; elution by $1.0 \mathrm{~N} \mathrm{HCl}$; Cd(II): pH 8; elution by $0.5 \mathrm{~N} \mathrm{HNO}_{3}$ ].

\begin{tabular}{cccccc}
\hline Metal ions & $\begin{array}{c}\text { Volume of solution } \\
\text { passed }(\mathbf{m L})\end{array}$ & $\begin{array}{c}\text { Concentration of feed } \\
\text { solution }\left(\boldsymbol{\mu g} \cdot \mathbf{L}^{-1}\right)\end{array}$ & $\begin{array}{c}\text { Volume of eluted } \\
\text { solution }(\mathbf{m L})\end{array}$ & $\begin{array}{c}\text { Recovery } \\
(\mathbf{\%})\end{array}$ & $\begin{array}{c}\text { Preconcentration } \\
\text { Factor }(\mathbf{P F})\end{array}$ \\
\hline $\mathbf{N i}(\mathrm{II})$ & 1000 & Resin & & \\
$\mathbf{C u}(\mathrm{II})$ & 1000 & 8 & 9.5 & $97-98$ & 105 \\
$\mathbf{Z n}(\mathrm{II})$ & 1000 & 8 & 9.2 & 97 & 108 \\
$\mathbf{C d}(\mathrm{II})$ & 1000 & 8 & 10.5 & 97 & 95 \\
\hline
\end{tabular}

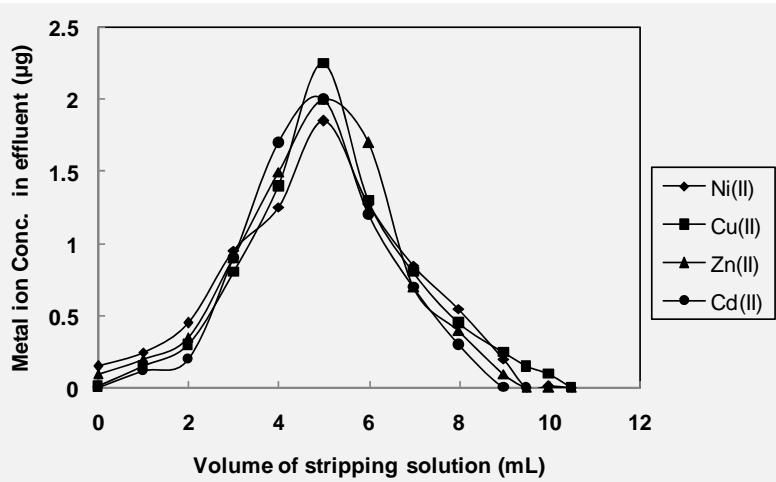

Figure 6. Evaluation of the stability of the resin for $\mathrm{Ni}(\mathrm{II})$, $\mathrm{Cu}(\mathrm{II}), \mathrm{Zn}(\mathrm{II})$ and $\mathrm{Cd}(\mathrm{II})$ by sorption and elution; Experimental condition: Amount of resin: $0.5 \mathrm{gm}$; volume of the feed solution: $100 \mathrm{~mL}$; concentration of feed solution: 300 $\mu \mathrm{g} \cdot \mathrm{mL}^{-1}$; $\mathrm{Ni}(\mathrm{II}): \mathrm{pH} 3.5$, elution by: $1.5 \mathrm{~N} \mathrm{HCl}$; $\mathrm{Cu}(\mathrm{II}): \mathrm{pH}$ 5.5, elution by: $1.0 \mathrm{~N} \mathrm{HNO}_{3} ; \mathrm{Zn}$ (II): $\mathrm{pH}$ 5.0, elution by: 1.0 $\mathrm{N} \mathrm{HCl}$; Cd(II): pH 8; elution by: $0.5 \mathrm{~N} \mathrm{HNO}_{3}$.

was found that the maximum change in the sorption and desorption agreed within 3\% - $4 \%$ error upto 8 - 10 cycles for all the matal ions that shows the efficiency of the sysnthesized resin (Figure 7).

\subsubsection{Effect of Electrolytes}

To evaluate the selectivity of the synthesized resin, the possible interference of electrolytes on the recovery of $\mathrm{Ni}(\mathrm{II}), \mathrm{Cu}(\mathrm{II}), \mathrm{Zn}(\mathrm{II})$ and $\mathrm{Cd}(\mathrm{II})$ was investigated and the results are summarized in Table 4. An error of 2\% - 3\% was considered to be within the range of experimental error. It was observed that except $\mathrm{Na}_{3} \mathrm{PO}_{4}$ and $\mathrm{NaF}$, all others electrolytes did not interfere between 1.5 to $4.0 \mathrm{M}$ concentrations (ranges), which further expand the potential application of resin for the analysis of real samples.

\section{Chromatographic Separations}

As observed from experimental practice synthesized resinposses very good sorption capacity, distribution coefficient and exchange kinetics, therefore it was further used for the separation of $\mathrm{Cu}(\mathrm{II}), \mathrm{Zn}$ (II) and $\mathrm{Cd}(\mathrm{II})$ from their binary and ternary mixtures by column method.

The mixtures of metal ions can be effectively separated by selective adjustment of the $\mathrm{pH}$ and eluting agents. Hence, the following mixtures (each $100 \mu \mathrm{g}$ in 25 $\mathrm{mL}$ buffer solution) were passed through the column at the $\mathrm{pH}$ of maximum sorption and optimum flow rate. The column effluents were analyzed for the metal ions by spectrophotometry/FAAS/ICP-AES.

\subsection{Separation of a Binary Mixture}

$100 \mu \mathrm{g}$ each of both $\mathrm{Zn}$ (II) and Cd(II) in $25 \mathrm{~mL}$ of buffer solution of $\mathrm{pH} 5.0$ at a flow rate of $1.0 \mathrm{~mL} \cdot \mathrm{min}^{-1}$ were passed through the column. At this $\mathrm{pH}, \mathrm{Cd}(\mathrm{II})$ was not sorbed on resin and it came out with the effluent while $\mathrm{Zn}$ (II) was retained in the column. $\mathrm{Zn}$ (II) was eluted with $24.5 \mathrm{~mL}, 1.0 \mathrm{~N} \mathrm{HCl}$. Quantitative separation was achieved in binary mixture as shown in their separation pattern in Figure 8(a).

\subsection{Separation of a Ternary Mixture}

$100 \mu \mathrm{g}$ each of $\mathrm{Cu}(\mathrm{II}), \mathrm{Zn}(\mathrm{II})$ and $\mathrm{Cd}(\mathrm{II})$ in $25 \mathrm{~mL}$ of buffer solution of $\mathrm{pH} 5.0$ at a flow rate of $1.0 \mathrm{~mL} \cdot \mathrm{min}^{-1}$ were passed through the column. At this $\mathrm{pH}, \mathrm{Cd}(\mathrm{II})$ was not sorbed on resin and it came out with the effluent, while $\mathrm{Cu}$ (II) and $\mathrm{Zn}$ (II) were retained in the column. $\mathrm{Cu}(\mathrm{II})$ and $\mathrm{Zn}$ (II) were separated on the basis of selective eluting agents. $\mathrm{Zn}$ (II) was eluted first with $25 \mathrm{~mL}, 1.0 \mathrm{~N}$ $\mathrm{HCl}$ followed by $\mathrm{Cu}(\mathrm{II})$ with $22.5 \mathrm{~mL}, 1.0 \mathrm{~N}_{\mathrm{HNO}_{3}}$. Quantitative separation was achieved in the ternary mixture as shown in their separation patterns in Figure 8(b).

\section{Limit of Quantification and Application}

Selectivity and sensitivity are two important factors in the extraction and the separation process. To check the capability of the resin to detect trace amounts of metal ions, studies were performed by passing $1000 \mathrm{~mL}$ of sample solutions containing metal ions in the range of 5 $10 \mu \mathrm{g}$ through the optimized column. The quantification limit for $\mathrm{Ni}(\mathrm{II}), \mathrm{Cu}(\mathrm{II}), \mathrm{Zn}(\mathrm{II})$ and $\mathrm{Cd}(\mathrm{II})$ for resin were 
Table 4. Tolerance limits of electrolytes on the sorption of $\mathrm{Ni}(\mathrm{II}), \mathrm{Cu}(\mathrm{II}), \mathrm{Zn}$ (II) and $\mathrm{Cd}(\mathrm{II})$ on resin. [Experimental Conditions: resin: $1.0 \mathrm{gm}$; volume of solution passed: $100 \mathrm{~mL}$; $\mathrm{Ni}(\mathrm{II}): \mathrm{pH} 3.5$; $\mathrm{Cu}(\mathrm{II}): \mathrm{pH} 5.5$; $\mathrm{Zn}(\mathrm{II}): \mathrm{pH}$ 5.0; Cd(II): pH 8.0].

\begin{tabular}{|c|c|c|c|c|c|c|c|}
\hline \multirow{2}{*}{$\begin{array}{c}\text { Metal ions } \\
2.5\left(\mu \mathrm{g} \cdot \mathrm{mL}^{-1}\right)\end{array}$} & \multicolumn{7}{|c|}{ Concentrations of electrolytes $\left(\mathrm{mol} \cdot \mathrm{L}^{-1}\right)$} \\
\hline & $\mathrm{NaF}$ & $\mathrm{NaCl}$ & $\mathrm{NaBr}$ & $\mathrm{NaNO}_{2}$ & $\mathrm{Na}_{2} \mathrm{SO}_{4}$ & $\mathrm{Na}_{3} \mathrm{PO}_{4}$ & $\mathrm{CH}_{3} \mathrm{COONa}$ \\
\hline \multicolumn{8}{|c|}{ Resin } \\
\hline $\mathrm{Ni}(\mathrm{II})$ & 0.7 & 2.4 & 1.9 & 2.5 & 2.1 & 1.3 & 2.2 \\
\hline $\mathrm{Cu}(\mathrm{II})$ & 0.8 & 2.7 & 2.0 & 3.1 & 2.2 & 1.2 & 2.1 \\
\hline Zn(II) & 1.0 & 3.0 & 1.6 & 2.9 & 1.9 & 1.1 & 1.9 \\
\hline $\mathrm{Cd}(\mathrm{II})$ & 0.6 & 2.0 & 1.3 & 2.8 & 1.6 & 1.0 & 2.0 \\
\hline
\end{tabular}

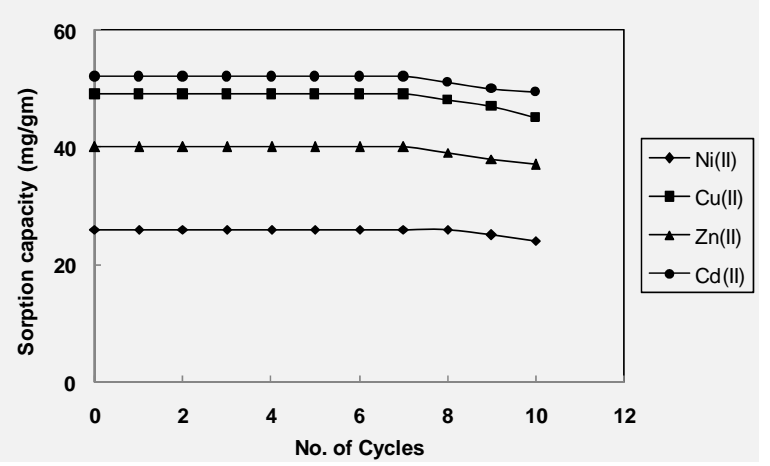

Figure 7. The elution profile of $\mathrm{Ni}(\mathrm{II}), \mathrm{Cu}(\mathrm{II}), \mathrm{Zn}$ (II) and Cd(II) on theresin; Experimental conditions: Amount of resin: $1.0 \mathrm{gm}$; concentration of the solution passed: 1000 $\mathrm{mL}, 8 \mu \mathrm{g} \cdot \mathrm{L}^{-1}$; $\mathrm{Ni}(\mathrm{II})$ : $\mathrm{pH}$ : 3.5; elution by $1.5 \mathrm{~N} \mathrm{HCl}$; $\mathrm{Cu}(\mathrm{II})$ : pH: 5.5; elution by $1.0 \mathrm{~N} \mathrm{HNO}_{3}$; Zn(II): pH: 5.0 ; elution by $1.0 \mathrm{~N} \mathrm{HCl}$; $\mathrm{Cd}(\mathrm{II}): \mathrm{pH}: 8.0$; elution by $0.5 \mathrm{~N} \mathrm{HNO}_{3}$.

found to be $6.4,5.4,5.0$ and $9.0 \mu \mathrm{g} \cdot \mathrm{L}^{-1}$, respectively, indicating the resin's capability to extract the trace metal ions of interest from the real samples. To check the applicability and validity of the proposed method, synthesized resin was subjected to various water sample analyses and the results are compared by the standard procedure. The data is given in Table 5.

\section{Comparison with Other Solid Phase Extraction Methods}

Comparison of sorption capacity and preconcentration factor of different adsorbents are summarized in Table 6.

\section{Conclusion}

Octa-O-methoxy resorcin [4] arene Amberlite XAD-4, a newly synthesized polymeric chelating resin was successfully applied for the selective separation, preconcentration and determination of metal ions such as $\mathrm{Ni}(\mathrm{II})$, $\mathrm{Cu}(\mathrm{II}), \mathrm{Zn}(\mathrm{II})$ and $\mathrm{Cd}(\mathrm{II})$ from real samples. The advantages found in the synthesized resin are its faster exchange rates, better sorption capacity and high preconcentration factors. The resin was found to be highly selective in

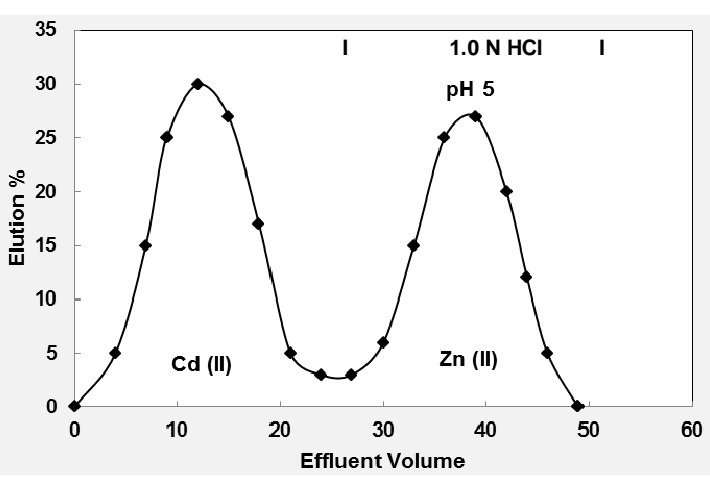

(a)

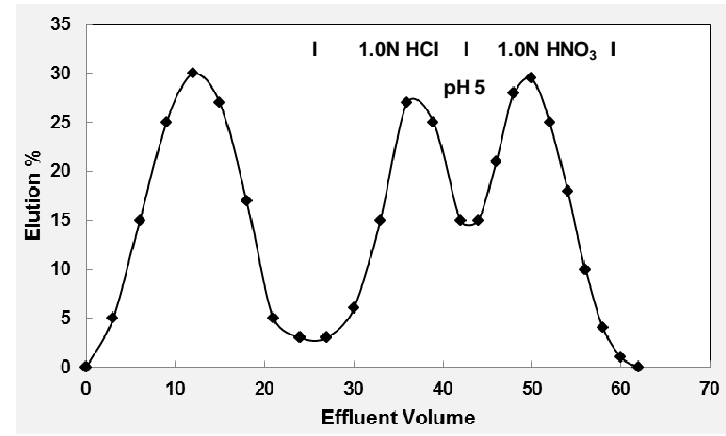

(b)

Figure 8. (a) Separation of $\mathrm{Zn}$ (II) and Cd(II) on theresin. Experimental conditions: Amount of resin: $1.0 \mathrm{gm}$; column maintained at pH 5.0; $\mathrm{Zn}(\mathrm{II}): 100 \mu \mathrm{g}$ in $25 \mathrm{~mL}$ buffer: elution by $1.0 \mathrm{~N} \mathrm{HCl}$; Cd(II): $100 \mu \mathrm{g}$ in $25 \mathrm{~mL}$ buffer: elution by $0.5 \mathrm{~N} \mathrm{HNO}_{3}$; (b) Separation of $\mathrm{Cu}(\mathrm{II}), \mathrm{Zn}$ (II) and $\mathrm{Cd}(\mathrm{II})$ on theresin; Experimental conditions: Amount of resin: 1.0 gm; column maintained at pH 5.0;Cu(II): $100 \mu \mathrm{g}$ in $25 \mathrm{~mL}$ buffer: elution by $1.0 \mathrm{~N} \mathrm{HNO}_{3}$; Zn(II): $100 \mu \mathrm{g}$ in $25 \mathrm{ml}$ buffer: elution by 1.0N HCl; Cd(II): $100 \mu \mathrm{g}$ in $25 \mathrm{~mL}$ buffer: elution by $0.5 \mathrm{~N} \mathrm{HNO}_{3}$.

extracting the analyses in the presence of various electrolytes. The reusability of resin was about 8 to 10 cycles without any significant loss in its sorption behavior. Separations of binary/ternary mixtures of metal ions are possible by control of $\mathrm{pH}$ or gradient elution. Sorption capacity of $\mathrm{Ni}(\mathrm{II}), \mathrm{Cu}(\mathrm{II}), \mathrm{Zn}$ (II) and $\mathrm{Cd}(\mathrm{II})$, attained by resin was found to be reasonably better than some al- 
Table 5. Determination of $\mathrm{Ni}(\mathrm{II}) \mathrm{Cu}(\mathrm{II}), \mathrm{Zn}(\mathrm{II})$ and $\mathrm{Cd}(\mathrm{II})$ in natural water samples on resin. [Experimental conditions: resin: $1.0 \mathrm{gm}$; sample volume: $1000 \mathrm{~mL}$.

\begin{tabular}{|c|c|c|c|c|c|c|c|c|c|}
\hline \multirow{2}{*}{ Sample } & \multirow{2}{*}{ Method } & \multicolumn{2}{|c|}{$\mathrm{Ni}(\mathrm{II})$} & \multicolumn{2}{|c|}{$\mathrm{Cu}(\mathrm{II})$} & \multicolumn{2}{|c|}{ Zn(II) } & \multicolumn{2}{|c|}{ Cd(II) } \\
\hline & & $\begin{array}{l}\text { Amount } \\
\left(\mu \mathrm{g} \cdot \mathrm{L}^{-1}\right)\end{array}$ & $\begin{array}{c}\text { R.S.D. } \\
(\%)\end{array}$ & $\underset{\left(\mu g \cdot L^{-1}\right)}{\text { Amount }}$ & $\begin{array}{c}\text { R.S.D. } \\
(\%)\end{array}$ & $\underset{\left(\mu g \cdot L^{-1}\right)}{\text { Amount }}$ & $\begin{array}{c}\text { R.S.D. } \\
\text { (\%) }\end{array}$ & $\underset{\left(\mu g \cdot L^{-1}\right)}{\text { Amount }}$ & $\begin{array}{c}\text { R.S.D } \\
(\%)\end{array}$ \\
\hline \multirow{2}{*}{$\begin{array}{l}\text { Sabarmati river, } \\
\text { near thermal } \\
\text { power station, } \\
\text { Ahmedabad }\end{array}$} & $\begin{array}{l}\text { Present } \\
\text { method }\end{array}$ & 12 & 1.25 & 41 & 1.15 & 14 & 1.15 & 13 & 1.15 \\
\hline & $\begin{array}{l}\text { Standard } \\
\text { addition }\end{array}$ & 13 & 1.2 & 44 & 1.0 & 16 & 1.0 & 15 & 1.4 \\
\hline \multirow{2}{*}{$\begin{array}{c}\text { Ground water, } \\
\text { university area, } \\
\text { Ahmedabad }\end{array}$} & $\begin{array}{l}\text { Present } \\
\text { method }\end{array}$ & 11 & 1.65 & 11 & 1.2 & 12 & 1.15 & 13 & 1.35 \\
\hline & $\begin{array}{l}\text { Standard } \\
\text { addition }\end{array}$ & 13 & 1.25 & 15 & 1.3 & 15 & 1.25 & 14.5 & 1.15 \\
\hline $\begin{array}{l}\text { Ground water, } \\
\text { Vatva Industrial }\end{array}$ & $\begin{array}{l}\text { Present } \\
\text { method }\end{array}$ & 26 & 1.6 & 56 & 1.3 & 29 & 1.3 & 41 & 1.1 \\
\hline
\end{tabular}

Table 6. Comparable methods for preconcentration and determination of $\mathrm{Ni}(\mathrm{II}), \mathrm{Cu}$ (II), $\mathrm{Zn}$ (II) and $\mathrm{Cd}(\mathrm{II})$.

\begin{tabular}{|c|c|c|c|c|c|c|c|c|c|c|}
\hline \multirow[t]{2}{*}{ No } & \multirow[t]{2}{*}{ Adsorbent } & \multicolumn{4}{|c|}{ Sorption capacity $(\mu \mathrm{g} / \mathrm{gm})$} & \multicolumn{4}{|c|}{ Preconcentration factor } & \multirow[t]{2}{*}{ Ref } \\
\hline & & $\mathrm{Ni}(\mathrm{II})$ & $\mathrm{Cu}(\mathrm{II})$ & $\mathrm{Zn}(\mathrm{II})$ & Cd(II) & $\mathrm{Ni}(\mathrm{II})$ & $\mathrm{Cu}(\mathrm{II})$ & Zn(II) & Cd(II) & \\
\hline 1 & $\begin{array}{l}\text { Polystyrene divinylbenzene } \\
\text { resin functionalized by } \\
\text { 1-(2-pyridylazo) 2-naphtol } \\
\text { (XAD-16-PAN) }\end{array}$ & & & & 7500 & & & & & [85] \\
\hline 2 & $\begin{array}{l}\text { 1,6-Bis(2-carboxy aldehyde } \\
\text { phenoxy)butane-XAD-16 }\end{array}$ & & 5380 & & 4436 & & 100 & & 100 & [86] \\
\hline 3 & $\begin{array}{l}\text { Polyethyleneiminemethylene } \\
\text { phosphonic acid }\end{array}$ & & 85,690 & & & & & & & [87] \\
\hline 4 & $\begin{array}{c}\text { Alumina- }(\mathrm{N}-\{4-[4-\{1-[4- \\
\text { (dimethylamino)phenyl]methylidene }\}- \\
5-(4-\mathrm{H}) \text { oxazolone]phenyle }\} \text { acetamide }\end{array}$ & & 8000 & & 14,000 & & 400 & & 160 & [88] \\
\hline 5 & MWCNTs-(D2EHPA-TOPO) & & 4900 & 4789 & & & & & & [89] \\
\hline 6 & $\begin{array}{l}\text { 8-Hydroxyquinoline } \\
\text { Amberlite IR-120 }\end{array}$ & & 24,814 & & & & $>166$ & & & [1] \\
\hline 7 & Dowex optipore SD-2 & 11,500 & 12,000 & & & & & & & \\
\hline 8 & Gallic acid-modified silica gel & & 15,380 & & 6090 & & 200 & & 100 & [90] \\
\hline 9 & Dowex optipore SD-2 & 11,500 & 12,000 & & & & & & & [91] \\
\hline 10 & $\begin{array}{l}\text { p-tert-butylcalix [4] arene-1,2-crown- } \\
\text { 4-anchored chloromethylated } \\
\text { polymeric resin }\end{array}$ & & 13,652 & 9744 & 23,042 & & 208 & 119 & 199 & [92] \\
\hline 11 & $\begin{array}{c}\text { Octa- } O \text {-methoxy resorcin }[4] \text { arene } \\
\text { Amberrlite XAD-4 resin }\end{array}$ & 26,000 & 49,650 & 40,499 & 52,310 & 105 & 108 & 95 & 112 & \\
\hline
\end{tabular}

ready reported solid phase extractants indicating the resin's potential capability to extract the metal ions at trace level in the natural and ground water samples.

\section{Acknowledgements}

The authors gratefully acknowledge the financial assistance provided by University Grant Commission (UGC) New Delhi and GUJCOST. The authors also acknowledge CSMCRI (Bhavanagar), GFSU (Gandhinagar), DFS
(Ahmedabad), CDRI (Lucknow) for providing instrumental facilities and INFLIBNET, Ahmedabad, for ejournals.

\section{REFERENCES}

[1] A. Daneshfar, M. Ghaedi, S. Vafafard, L. Shiri, R. Sahrai, and M. Soylak, "Amberlite IR-120 Modified with 8-Hydroxyquinoline as Efficient Adsorbent for Solid-Phase Extraction and Flame Atomic Absorption Determination 
of Trace Amounts of Some Metal Ions," Biological Trace Element Research, Vol. 145, No. 2, 2012, pp. 240-247. doi:10.1007/s12011-011-9171-1

[2] M. Tüzen, "Determination of Heavy Metals in Soil, Mushroom and Plant Samples by Atomic Absorption Spectrometry," Microchemical Journal, Vol. 74, No. 3, 2003, pp. 289-297. doi:10.1016/S0026-265X(03)00035-3

[3] S. Arce, S. Cerutti, R. Olsina, M. R. Gomez and L. D. Martnez, "Trace Element Profile of a Wild Edible Mushroom (Suillus granulatus)," Journal of AOAC International, Vol. 91, No. 4, 2008, pp. 853-857.

[4] T. G. Kazi, N. Jalbani, N. Kazi, M. K. Jamali, M. B. Arain, H. I. Afridi, A. Kandhro and Z. Pirzado, "Evaluation of Toxic Metals in Blood and Urine Samples of Chronic Renal Failure Patients, before and after Dialysis," Renal Failure, Vol. 30, No. 7, 2008, pp. 737-745. doi:10.1080/08860220802212999

[5] E. Sesli, M. Tuzen and M. Soylak, "Evaluation of Trace Metal Contents of Some Wild Edible Mushrooms from Black Sea Region, Turkey," Journal of Hazardous Materials, Vol. 160, No. 2-3, 2008, pp. 462-467. doi:10.1016/i.jhazmat.2008.03.020

[6] E. P. Nardi, F. S. Evangelista, L. Tormen, A. J. Curtius, S. S. Souza and F. Barbosa, "The Use of Inductively Coupled Plasma Mass Spectrometry (ICP-MS) for the Determination of Toxic and Essential Elements in Different Types of Food Samples," Food Chemistry, Vol. 112, No. 3, 2009, pp. 727-732. doi:10.1016/i.foodchem.2008.06.010

[7] H. S. A. Sigel and K. O. Roland, "Nickel and Its Surprising Impact in Nature," Wiley, Hoboken, 2008.

[8] K. S. Kasprzak, F. W. Sunderman and K. Salnikow, "Nickel Carcinogenesis," Mutation Research/Fundamental and Molecular Mechanisms of Mutagenesis, Vol. 533, No. 1-2, 2003, pp. 67-97.

[9] J. K. Dunnick, M. R. Elwell, A. E. Radovsky, J. M. Benson, F. F. Hahn, K. J. Nikula, E. B. Barr and C. H. Hobbs, "Comparative Carcinogenic Effects of Nickel Subsulfide, Nickel Oxide, or Nickel Sulfate Hexahydrate Chronic Exposures in the Lung," Cancer Research, Vol. 55, No. 22, 1995, pp. 5251-5256.

[10] W. I. Oehme, "Frederick, Toxicity of Heavy Metal in the Environment Parts 1 \& 2," Marcel Dekke, New York, 1979.

[11] E. J. Underwood, "Trace Elements in Human and Animal Nutrition," 4th Edition, Academic Press, New York, 1977.

[12] D. O. A. S. Prasad, "Trace Metals in Human Health and Disease," Academic Press, New York, 1976.

[13] I. Tokgoz, C. A. Sahin and S. Bektas, "Determination of Copper Traces in Water Samples by Flow InjectionFlame Atomic Absorption Spectrometry Using a Novel Solidified Floating Organic Drop Microextraction Method," Microchemical Journal, Vol. 98, No. 2, 2011, pp. 215-219.

[14] M. P. L. Friberg, G. F. Nordberg and T. Kjellstrom, "Cadmium in the Environment," 2nd Edition, CRC Press, Cleveland, 1974.
[15] P. de Voogt, B. Van Hattum, J. F. Feenstra and J. W. C. Peereboom, "Exposure and Health Effects of Cadmium," Toxicological \& Environmental Chemistry, Vol. 3, No. 2, 1980, pp. 89-109. doi:10.1080/02772248009356939

[16] V. H. Ferm and S. J. Carpenter, "The Relationship of Cadmium and Zinc in Experimental Mammalian Teratogenesis," Laboratory Investigation: A Journal of Technical Methods and Pathology, Vol. 18, No. 4, 1968, pp. 429-432.

[17] T. Kjellström, L. Friberg and B. Rahnster, "Mortality and Cancer Morbidity among Cadmium-Exposed Workers," Environmental Health Perspectives, Vol. 28, 1979, pp. 199-204.

[18] M. D. Kipling and J. A. H. Waterhouse, "Cadmium and Prostatic Carcinoma," The Lancet, Vol. 289, No. 7492, 1967, pp. 730-731. doi:10.1016/S0140-6736(67)92222-2

[19] C. L. Potts, "Cadmium Proteinuria-The Health of Battery Workers Exposed to Cadmium Oxide Dust," Annals of Occupational Hygiene, Vol. 8, No. 1, 1965, pp. 55-61. doi:10.1093/annhyg/8.1.55

[20] M. I. Khoder, S. K. Hassan and A. A. El-Abssawy, "An Evaluation of Loading Rate of Dust, $\mathrm{Pb}, \mathrm{Cd}$, and $\mathrm{Ni}$ and Metals Mass Concentration in the Settled Surface Dust in Domestic Houses and Factors Affecting Them," Indoor and Built Environment, Vol. 19, No. 3, 2010, pp. 391-399. doi:10.1177/1420326X10367284

[21] M. Soylak and M. Do, "Column Preconcentration of Trace Amounts of Copper on Activated Carbon from Natural Water Samples," Analytical Letters, Vol. 29, No. 4, 1996, pp. 635-643. doi:10.1080/00032719608000426

[22] J. S. Suleiman, B. Hu, C. Huang and N. Zhang, "Determination of $\mathrm{Cd}, \mathrm{Co}, \mathrm{Ni}$ and $\mathrm{Pb}$ in Biological Samples by Microcolumn Packed with Black Stone (Pierre Noire) Online Coupled with ICP-OES," Journal of Hazardous Materials, Vol. 157, No. 2-3, 2008, pp. 410-417. doi:10.1016/j.jhazmat.2008.01.014

[23] F. Xie, X. Lin, X. Wu and Z. Xie, "Solid Phase Extraction of Lead(II), Copper(II), Cadmium(II) and Nickel(II) Using Gallic Acid-Modified Silica Gel Prior to Determination by Flame Atomic Absorption Spectrometry," Talanta, Vol. 74, No. 4, 2008, pp. 836-843. doi:10.1016/j.talanta.2007.07.018

[24] V. S. Ozdemir, E. Kilınc, H. Bilgetekin, A. Dundar and B. Ziyadanogulları, "Pleurotus Eryngii Immobilized Amberlitexad-16 as a Solid-Phase Biosorbent for Preconcentrations of $\mathrm{Cd}^{2+}$ and $\mathrm{Co}^{2+}$ and Their Determination by ICPOES," Talanta, Vol. 106, 2013, p. 367.

[25] Q. Wang, X. Chang, D. Li, Z. Hu, R. Li and Q. He, “Adsorption of Chromium(III), Mercury(II) and Lead(II) Ions onto 4-Aminoantipyrine Immobilized Bentonite," Journal of Hazardous Materials, Vol. 186, No. 2-3, 2011, pp. 1076-1081. doi:10.1016/j.jhazmat.2010.11.107

[26] M. Ghaedi, K. Niknam, K. Taheri, H. Hossainian and M. Soylak, "Flame Atomic Absorption Spectrometric Determination of Copper, Zinc and Manganese after SolidPhase Extraction Using 2,6-Dichlorophenyl-3, 3-Bis (Indolyl) Methane Loaded on Amberlite XAD-16," Food and Chemical Toxicology, Vol. 48, No. 3, 2010, pp. 891897. doi:10.1016/j.fet.2009.12.029 
[27] A. R. Türker, "Separation, Preconcentration and Speciation of Metal Ions by Solid Phase Extraction," Separation \& Purification Reviews, Vol. 41, No. 3, 2012, pp. 169-206. doi:10.1080/15422119.2011.585682

[28] F. Marahel, M. Ghaedi, M. Montazerozohori, M. Nejati Biyareh, S. Nasiri Kokhdan and M. Soylak, "Solid-Phase Extraction and Determination of Trace Amount of Some Metal Ions on Duolite XAD 761 Modified with a New Schiff Base as Chelating Agent in Some Food Samples," Food and Chemical Toxicology, Vol. 49, No. 1, 2011, pp. 208-214. doi:10.1016/j.fct.2010.10.018

[29] P. Gopi Krishna, J. Mary Gladis, U. Rambabu, T. Prasada Rao and G. R. K. Naidu, "Preconcentrative Separation of Chromium(VI) Species from Chromium(III) by Coprecipitation of Its Ethyl Xanthate Complex onto Naphthalene," Talanta, Vol. 63, No. 3, 2004, pp. 541-546. doi:10.1016/j.talanta.2003.11.032

[30] K. Saito, I. Taninaka, S. Murakami and A. Muromatsu, "Extraction Behaviour of Copper(II) and Silver(I) with a Thiacrown Ether Carboxylic Acid, 2-(3,6,10,13-Tetrathiacyclotetradec-1-oxy) Hexanoic Acid," Talanta, Vol. 46, No. 5, 1998, pp. 1187-1194. doi:10.1016/S0039-9140(97)00365-2

[31] M. Soylak, N. D. Erdogan and L. Elci, "Membrane Filtration of Iron(III), Copper(II) and Lead(II) Ions as 1-(2Pyridylazo) 2-Naphtol (PAN) for Their Preconcentration and Atomic Absorption Determinations," Journal of the Chinese Chemical Society Taipei, Vol. 51, 2004, pp. 703-706.

[32] E. Paleologos, C. Stalikas, S. Tzouwara-Karayanni and M. Karayannis, "Selective Speciation of Trace Chromium through Micelle-Mediated Preconcentration, Coupled with Micellar Flow Injection Analysis-Spectrofluorimetry," Analytica Chimica Acta, Vol. 436, No. 1, 2001, pp. 49-57. doi:10.1016/S0003-2670(01)00884-4

[33] A. Safavi, H. Abdollahi, M. R. Hormozi Nezhad and R. Kamali, "Cloud Point Extraction, Preconcentration and Simultaneous Spectrophotometric Determination of Nickel and Cobalt in Water Samples," Spectrochimica Acta Part A: Molecular and Biomolecular Spectroscopy, Vol. 60, No. 12, 2004, pp. 2897-2901. doi:10.1016/i.saa.2004.02.001

[34] K. Čundeva, T. Stafilov and G. Pavlovska, "Preconcentration and Separation of Iron in Water by Coflotation Using Lead(II) Hexamethylenedithiocarbamate," Spectrochimica Acta Part B: Atomic Spectroscopy, Vol. 55, No. 7, 2000, pp. 1081-1087. doi:10.1016/S0584-8547(00)00161-0

[35] A. Bazzi, B. Kreuz, J. Wuokila and A. Maqboul, "Separation and Determination of $\mathrm{Cr}(\mathrm{III})$ and $\mathrm{Cr}(\mathrm{VI})$ with CationExchange Chromatography and Atomic Absorption Spectroscopy. An Experiment for Quantitative Methods of Analysis," Journal of Chemical Education, Vol. 82, No. 3, 2005, p. 435. doi:10.1021/ed082p435

[36] V. Camel, "Solid Phase Extraction of Trace Elements," Spectrochimica Acta Part B: Atomic Spectroscopy, Vol. 58, No. 7, 2003, pp. 1177-1233. doi:10.1016/S0584-8547(03)00072-7

[37] A. Mellah and D. Benachour, "The Solvent Extraction of Zinc and Cadmium from Phosphoric Acid Solution by
Di-2-Ethyl Hexyl Phosphoric Acid in Kerosene Diluent," Chemical Engineering and Processing: Process Intensification, Vol. 45, No. 8, 2006, pp. 684-690. doi:10.1016/j.cep.2006.02.004

[38] C. Ji, R. Qu, C. Wang, H. Chen, C. Sun, Q. Xu, Y. Sun and C. Wei, "A Chelating Resin with Bis[2-(2-benzothiazolylthioethyl)sulfoxide]: Synthesis, Characterization and Properties for the Removal of Trace Heavy Metal Ion in Water Samples," Talanta, Vol. 73, No. 2, 2007, pp. 195-201. doi:10.1016/j.talanta.2007.03.043

[39] G. Sheng, J. Li, D. Shao, J. Hu, C. Chen, Y. Chen and X. Wang, "Adsorption of Copper(II) on Multiwalled Carbon Nanotubes in the Absence and Presence of Humic or Fulvic Acids," Journal of Hazardous Materials, Vol. 178, No. 1-3, 2010, pp. 333-340. doi:10.1016/j.jhazmat.2010.01.084

[40] A. R. Ghiasvand, R. Ghaderi and A. Kakanejadifard, "Selective Preconcentration of Ultra Trace Copper(II) Using Octadecyl Silica Membrane Disks Modified by a Recently Synthesized Glyoxime Derivative," Talanta, Vol. 62, No. 2, 2004, pp. 287-292. doi:10.1016/j.talanta.2003.07.011

[41] F. Shemirani, A. A. Mirroshandel, M. Salavati Niasari and R. Rahnama Kozani, "Silica Gel Coated with Schiff's Base: Synthesis and Application as an Adsorbent for Cadmium, Copper, Zinc, and Nickel Determination after Preconcentration by Flame Atomic Absorption Spectrometry," Journal of Analytical Chemistry, Vol. 59, No. 3, 2004, pp. 228-233. doi:10.1023/B:JANC.0000018964.41166.6a

[42] A. A. Ensafi, T. Khayamian and M. H. Karbasi, "On-Line Preconcentration System for Lead(II) Determination in Waste Water by Atomic Absorption Spectrometry Using Active Carbon Loaded with Pyrogallol Red," Analytical Sciences, Vol. 19, No. 6, 2003, pp. 953-956. doi:10.2116/analsci.19.953

[43] S. L. C. Ferreira, H. Andrade and H. C. dos Santos, "Characterization and Determination of the Thermodynamic and Kinetic Properties of the Adsorption of the Molybdenum(VI)-Calmagite Complex onto Active Carbon," Journal of Colloid and Interface Science, Vol. 270, No. 2, 2004, pp. 276-280. doi:10.1016/j.jcis.2003.07.042

[44] H. Karami, M. F. Mousavi, Y. Yamini and M. Shamsipur, "On-Line Preconcentration and Simultaneous Determination of Heavy Metal Ions by Inductively Coupled PlasmaAtomic Emission Spectrometry," Analytica Chimica Acta, Vol. 509, No. 1, 2004, pp. 89-94. doi:10.1016/j.aca.2003.12.022

[45] P. Daorattanachai, F. Unob and A. Imyim, "Multi-Element Preconcentration of Heavy Metal Ions from Aqueous Solution by APDC Impregnated Activated Carbon," Talanta, Vol. 67, No. 1, 2005, pp. 59-64. doi:10.1016/j.talanta.2005.02.006

[46] A. N. Anthemidis, G. A. Zachariadis and J. A. Stratis, "On-Line Preconcentration and Determination of Copper, Lead and Chromium(VI) Using Unloaded Polyurethane Foam Packed Column by Flame Atomic Absorption Spectrometry in Natural Waters and Biological Samples," Talanta, Vol. 58, No. 5, 2002, pp. 831-840. doi:10.1016/S0039-9140(02)00373-9 
[47] Z. Fan, B. Hu and Z. Jiang, "Speciation Analysis of Vanadium in Natural Water Samples by Electrothermal Vaporization Inductively Coupled Plasma Optical Emission Spectrometry after Separation/Preconcentration with Thenoyltrifluoroacetone Immobilized on Microcrystalline Naphthalene," Spectrochimica Acta Part B: Atomic Spectroscopy, Vol. 60, No. 1, 2005, pp. 65-71. doi:10.1016/j.sab.2004.10.004

[48] J. Otero-Romaní, A. Moreda-Piñeiro, A. Bermejo-Barrera and P. Bermejo-Barrera, "Evaluation of Commercial C18 Cartridges for Trace Elements Solid Phase Extraction from Seawater Followed by Inductively Coupled PlasmaOptical Emission Spectrometry Determination," Analytica Chimica Acta, Vol. 536, No. 1-2, 2005, pp. 213-218. doi:10.1016/j.aca.2004.12.046

[49] T. Ferri and P. Sangiorgio, "Determination of Selenium Speciation in River Waters by Adsorption on Iron(III)Chelex-100 Resin and Differential Pulse Cathodic Stripping Voltammetry," Analytica Chimica Acta, Vol. 321, No. 2-3, 1996, pp. 185-193. doi:10.1016/0003-2670(95)00569-2

[50] G. Absalan, and M. A. Mehrdjardi, "Separation and Preconcentration of Silver Ion Using 2-Mercaptobenzothiazole Immobilized on Surfactant-Coated Alumina," Separation and Purification Technology, Vol. 33, No. 1, 2003, pp. 95-101. doi:10.1016/S1383-5866(03)00003-0

[51] V. A. Lemos, L. N. Santos and M. A. Bezerra, "Determination of Cobalt and Manganese in Food Seasonings by Flame Atomic Absorption Spectrometry after Preconcentration with 2-Hydroxyacetophenone-Functionalized Polyurethane Foam," Journal of Food Composition and Analysis, Vol. 23, No. 3, 2010, pp. 277-281. doi:10.1016/j.jfca.2009.11.004

[52] E. M. Soliman and S. A. Ahmed, "Solid-Phase Extractors Based on 8-Aminoquinoline and 2-Aminopyridine Covalently Bonded to Silica Gel for the Selective Separation and Determination of Calcium in Natural Water and Pharmaceutical Samples," Analytical Sciences, Vol. 26, No. 4, 2010, pp. 473-478. doi:10.2116/analsci.26.473

[53] A. S. Pereira, G. Ferreira, L. Caetano, R. S. D. Castro, A. Santos, P. M. Padilha and G. R. Castro, "4-Amine-2mercaptopyrimidine Modified Silica Gel Applied in Cd(II) and $\mathrm{Pb}(\mathrm{II})$ Extraction from an Aqueous Medium," Polish Journal of Chemical Technology, Vol. 12, No. 1, 2010, pp. 7-11. doi:10.2478/v10026-010-0002-5

[54] N. Pourreza and K. Ghanemi, "Solid Phase Extraction of Cadmium on 2-Mercaptobenzothiazole Loaded on Sulfur Powder in the Medium of Ionic Liquid 1-Butyl-3-methylimidazolium Hexafluorophosphate and Cold Vapor Generation-Atomic Absorption Spectrometric Determination," Journal of Hazardous Materials, Vol. 178, No. 1-3, 2010, pp. 566-571. doi:10.1016/j.jhazmat.2010.01.122

[55] L. Elci, D. Sahan, A. Basaran and M. Soylak, "Solid Phase Extraction Of Gold(III) on Amberlite XAD-2000 Prior to Its Flame Atomic Absorption Spectrometric Determination," Environmental Monitoring and Assessment, Vol. 132, No. 1-3, 2007, pp. 331-338. doi:10.1007/s10661-006-9537-6

[56] J. M. Traviesa-Alvarez, J. M. Costa-Fernandez, R. Pereiro and A. Sanz-Medel, "Direct Screening of Tetracyclines in
Water and Bovine Milk Using Room Temperature Phosphorescence Detection," Analytica Chimica Acta, Vol. 589, No. 1, 2007, pp. 51-58. doi:10.1016/j.aca.2007.02.063

[57] M. Benamor, Z. Bouariche, T. Belaid and M. T. Draa, "Kinetic Studies on Cadmium Ions by Amberlite XAD7 Impregnated Resins Containing Di(2-ethylhexyl) Phosphoric Acid as Extractant," Separation and Purification Technology, Vol. 59, No. 1, 2008, pp. 74-84. doi:10.1016/j.seppur.2007.05.031

[58] S. Boussetta, C. Branger, A. Margaillan, J. L. Boudenne and B. Coulomb, "Salicylic Acid and Derivatives Anchored on Poly(Styrene-co-Divinylbenzene) Resin and Membrane via a Diazo Bridge: Synthesis, Characterisation and Application to Metal Extraction," Reactive and Functional Polymers, Vol. 68, No. 3, 2008, pp. 775-786. doi:10.1016/j.reactfunctpolym.2007.11.017

[59] R. Navarro, I. Saucedo, A. Núñez, M. Ávila and E. Guibal, "Cadmium Extraction from Hydrochloric Acid Solutions Using Amberlite XAD-7 Impregnated with Cyanex 921 (Tri-Octyl Phosphine Oxide)," Reactive and Functional Polymers, Vol. 68, No. 2, 2008, pp. 557-571. doi:10.1016/j.reactfunctpolym.2007.10.027

[60] N. Rajesh, R. K. Jalan and P. Hotwany, "Solid Phase Extraction of Chromium(VI) from Aqueous Solutions by Adsorption of Its Diphenylcarbazide Complex on an Amberlite XAD-4 Resin Column," Journal of Hazardous Materials, Vol. 150, No. 3, 2008, pp. 723-727. doi:10.1016/j.jhazmat.2007.05.025

[61] Ş. Tokalıŏlu and Ş. Kartal, "Synthesis and Application of a New Chelating Resin Functionalized with Salicylaldoxime for the Determination of $\mathrm{Pb}(\mathrm{II}), \mathrm{Ni}(\mathrm{II}), \mathrm{Cu}(\mathrm{II})$ and $\mathrm{Mn}$ (II) Ions in Water Samples by Flame Atomic Absorption Spectrometry," Microchimica Acta, Vol. 162, No. 1-2, 2008, pp. 87-92. doi:10.1007/s00604-007-0841-9

[62] S. Z. Mohammadi, D. Afzali, M. A. Taher and H. Darijani, "Flame Atomic Absorption Spectrometry Determination of Trace Amounts of Cadmium and Zinc in Water Samples after Preconcentration onto Modified Amberlite XAD-4 Resin," CLEAN-Soil, Air, Water, Vol. 38, No. 2, 2010, pp. 140-145. doi:10.1002/clen.200900103

[63] H. Ciftci, "Separation and Preconcentration of Cobalt Using a New Schiff Base Derivative on Amberlite XAD-7," CLEAN-Soil, Air, Water, Vol. 38, No. 7, 2010, 657-662.

[64] G. Venkatesh, A. K. Jain and A. K. Singh, "2,3-Dihydroxypyridine Loaded Amberlite XAD-2 (AXAD-2-DHP): Preparation, Sorption-Desorption Equilibria with Metal Ions, and Applications in Quantitative Metal Ion Enrichment from Water, Milk and Vitamin Samples," Microchimica Acta, Vol. 149, No. 3-4, 2005, pp. 213-221. doi:10.1007/s00604-005-0320-0

[65] D. Prabhakaran and M. S. Subramanian, "Selective Extraction of U(VI), Th(IV), and La(III) from Acidic Matrix Solutions and Environmental Samples Using Chemically Modified Amberlite XAD-16 Resin," Analytical and Bioanalytical Chemistry, Vol. 379, No. 3, 2004, pp. 519525. doi:10.1007/s00216-004-2600-7

[66] I. Narin, M. Soylak, K. Kayakirilmaz, L. Elci and M. 
Dogan, Preparation of a Chelating Resin by Immobilizing 1-(2-Pyridylazo) 2-Naphtol on Amberlite XAD-16 and Its Application of Solid Phase Extraction of $\mathrm{Ni}(\mathrm{II}), \mathrm{Cd}(\mathrm{II})$, $\mathrm{Co}(\mathrm{II}), \mathrm{Cu}(\mathrm{II}), \mathrm{Pb}(\mathrm{II})$, and $\mathrm{Cr}(\mathrm{III})$ in Natural Water Samples," Analytical Letters, Vol. 36, No. 3, 2003, pp. 641658. doi:10.1081/AL-120018254

[67] D. Prabhakaran and M. S. Subramanian, "A New Chelating Sorbent for Metal Ion Extraction under High Saline Conditions," Talanta, Vol. 59, No. 6, 2003, pp. 12271236. doi:10.1016/S0039-9140(03)00030-4

[68] Y. Guo, B. Din, Y. Liu, X. Chang, S. Meng and J. Liu, "Preconcentration and Determination of Trace Elements with 2-Aminoacetylthiophenol Functionalized Amberlite XAD-2 by Inductively Coupled Plasma-Atomic Emission Spectrometry," Talanta, Vol. 62, No. 1, 2004, pp. 207213. doi:10.1016/S0039-9140(03)00423-5

[69] Y. Guo, B. Din, Y. Liu, X. Chang, S. Meng and M. Tian, "Preconcentration of Trace Metals with 2-(Methylthio) Aniline-Functionalized XAD-2 and Their Determination by Flame Atomic Absorption Spectrometry," Analytica Chimica Acta, Vol. 504, No. 2, 2004, pp. 319-324. doi:10.1016/j.aca.2003.10.059

[70] I. Narin, M. Tuzen and M. Soylak, "Aluminium Determination in Environmental Samples by Graphite Furnace Atomic Absorption Spectrometry after Solid Phase Extraction on Amberlite XAD-1180/Pyrocatechol Violet Chelating Resin," Talanta, Vol. 63, No. 2, 2004, pp. 411418. doi:10.1016/j.talanta.2003.11.005

[71] M. V. Dinu and E. S. Dragan, "Heavy Metals Adsorption on Some Iminodiacetate Chelating Resins as a Function of the Adsorption Parameters," Reactive and Functional Polymers, Vol. 68, No. 9, 2008, pp. 1346-1354. doi:10.1016/j.reactfunctpolym.2008.06.011

[72] P. Timmerman, W. Verboom and D. N. Reinhoudt, "Resorcinarenes," Tetrahedron, Vol. 52, No. 8, 1996, pp. 2663-2704. doi:10.1016/0040-4020(95)00984-1

[73] W. Sliwa, T. Zujewska and B. Bachowska, "Resorcinarenes," Polish Journal of Chemistry, Vol. 34, 2003, pp. 1079-1082

[74] V. K. Jain, S. G. Pillai, R. A. Pandya, Y. K. Agrawal and P. S. Shrivastav, "Molecular Octopus: Octa Functionalized Calix [4] Resorcinarene-Hydroxamic Acid [C4RAHA] for Selective Extraction, Separation and Preconcentration of U(VI)," Talanta, Vol. 65, No. 2, 2005, pp. 466-475. doi:10.1016/j.talanta.2004.06.033

[75] V. K. Jain, S. G. Pillai, R. A. Pandya, Y. K. Agrawal and P. S. Shrivastav, "Selective Extraction, Preconcentration and Transport Studies of Thorium(IV) Using Octa-Functionalized Calix [4] Resorcinarene-Hydroxamic Acid," Analytical Sciences, Vol. 21, No. 2, 2005, pp. 129-135. doi:10.2116/analsci.21.129

[76] V. K. Jain, S. G. Pillai and P. H. Kanaiya, "Octafunctionalized Calix [4] Resorcinarene-N-Fenil-Acetohydroxamic Acid for the Separation, Preconcentration and Transport Studies of Cerium(IV)," Journal of the Brazilian Chemical Society, Vol. 17, No. 7, 2006, pp. 1316-1322. doi:10.1590/S0103-50532006000700018

[77] V. K. Jain, S. G. Pillap and H. C. Mandal, "Liquid-Liquid Extraction, Preconcentration and Transport Studies of
Lanthanum(III) with Calix [4] Resorcinarene-Hydroxamic Acid (C4RAHA)," Journal of the Chilean Chemical Society, Vol. 52, No. 2, 2007, pp. 1177-1181.

[78] A. F. D. de Namor and J. K. Chaaban, "A Partially Substituted Calix [4] Resorcarene Receptor and Its Selective Recognition for Soft Metal Cations (Silver and Mercury)," The Journal of Physical Chemistry B, Vol. 112, No. 7, 2008, pp. 2070-2077. doi:10.1021/jp077208s

[79] V. K. Jain, S. G. Pillai and H. S. Gupte, "Supervanadophile: Complexation, Preconcentration and Transport Studies of Vanadium by Octa Functionalized Calix [4] Resorcinarene-Hydroxamic Acid," Journal of the Iranian Chemical Society, Vol. 5, No. 4, 2008, pp. 646-656. doi:10.1007/BF03246146

[80] S. N. Podyachev, N. E. Burmakina, V. V. Syakaev, S. N. Sudakova, R. R. Shagidullin and A. I. Konovalov, "Synthesis, IR and NMR Characterization and Ion Extraction Properties of Tetranonylcalix [4] Resorcinol Bearing Acetylhydrazone Groups," Tetrahedron, Vol. 65, No. 1, 2009, pp. 408-417. doi:10.1016/j.tet.2008.10.008

[81] C. Gok, S. Seyhan, M. Merdivan and M. Yurdakoc, "Separation and Preconcentration of $\mathrm{La}^{3+}, \mathrm{Ce}^{3+}$ and $\mathrm{Y}^{3+}$ Using Calix [4] Resorcinarene Impregnated on Polymeric Support," Microchimica Acta, Vol. 157, No. 1-2, 2007, pp. 13-19. doi:10.1007/s00604-006-0646-2

[82] N. Demirel, M. Merdivan, N. Pirinccioglu and C. Hamamci, "Thorium(IV) and Uranium(VI) Sorption Studies on Octacarboxymethyl-C-Methylcalix [4] Resorcinarene Impregnated on a Polymeric Support," Analytica Chimica Acta, Vol. 485, No. 2, 2003, pp. 213-219. doi:10.1016/S0003-2670(03)00415-X

[83] D. Moore, G. W. Watson, T. Gunnlaugsson and S. E. Matthews, "Selective Formation of the rctt Chair Stereoisomers of Octa-O-Alkyl Resorcin [4] Arenes Using Brønsted Acid Catalysis," New Journal of Chemistry, Vol. 32, No. 6, 2008, pp. 994-1002. doi:10.1039/b714735j

[84] V. K. Jain, H. C. Mandalia, H. S. Gupte and D. J. Vyas, "Azocalix [4] Pyrrole Amberlite XAD-2: New Polymeric Chelating Resins for the Extraction, Preconcentration and Sequential Separation of $\mathrm{Cu}(\mathrm{II}), \mathrm{Zn}(\mathrm{II})$ and $\mathrm{Cd}(\mathrm{II})$ in Natural Water Samples," Talanta, Vol. 79, No. 5, 2009, pp. 1331-1340. doi:10.1016/j.talanta.2009.05.047

[85] M. B. Amran, A. S. Panggabean, A. Sulacman and M. Rusnadi, "Preparation of a Chelating Resin and Its Application as a Preconcentration System for Determination of Cadmium in River Water by Flow Injection Analysis," International Journal of Environmental Research, Vol. 5, No. 2, 2011, pp. 531-536.

[86] E. V. Oral, I. Dolak, H. Temel and B. Ziyadanogullari, "Preconcentration and Determination of Copper and Cadmium Ions with 1, 6-Bis(2-carboxy aldehyde phenoxy)butane Functionalized Amberlite XAD-16 by Flame Atomic Absorption Spectrometry," Journal of Hazardous Materials, Vol. 186, No. 1, 2011, pp. 724-730. doi:10.1016/j.jhazmat.2010.11.048

[87] N. Ferrah, O. Abderrahim, M. A. Didi and D. Villemin, "Removal of Copper Ions from Aqueous Solutions by a New Sorbent: Polyethyleneiminemethylene Phosphonic Acid," Desalination, Vol. 269, No. 1-3, 2011, pp. 17-24. 
doi:10.1016/j.desal.2010.11.035

[88] F. Sabermahani, M. A. Taher, H. Bahrami and S. Fozooni, "Alumina Coated with Oxazolone Derivative for Extraction of Trace Amounts of Cadmium and Copper from Water and Plant Samples," Journal of Hazardous Materials, Vol. 185, No. 2-3, 2011, pp. 945-950.

doi:10.1016/j.jhazmat.2010.09.111

[89] S. Vellaichamy and K. Palanivelu, "Preconcentration and Separation of Copper, Nickel and Zinc in Aqueous Samples by Flame Atomic Absorption Spectrometry after Column Solid-Phase Extraction onto MWCNTs Impregnated with D2EHPA-TOPO Mixture," Journal of Hazardous Materials, Vol. 185, No. 2-3, 2011, pp. 1131-1139. doi:10.1016/j.jhazmat.2010.10.023

[90] F. Xie, X. Lin, X. Wu and Z. Xie, "Solid Phase Extraction of Lead(II), Copper(II), Cadmium(II) and Nickel(II) Using Gallic Acid-Modified Silica Gel Prior to Determi- nation by flame Atomic Absorption Spectrometry," Talanta, Vol. 74, No. 4, 2008, pp. 836-843. doi:10.1016/j.talanta.2007.07.018

[91] M. Tuzen, M. Soylak, D. Citak, H. S. Ferreira, M. G. A. Korn and M. A. Bezerra, "A Preconcentration System for Determination of Copper and Nickel in Water and Food Samples Employing Flame Atomic Absorption Spectrometry," Journal of Hazardous Materials, Vol. 162, No. 2, 2009, pp. 1041-1045. doi:10.1016/j.jhazmat.2008.05.154

[92] S. Seyhan, M. Çolak, M. Merdivan and N. Demirel, "Solid Phase Extractive Preconcentration of Trace Metals Using p-tert-Butylcalix [4] Arene-1,2-crown-4-anchored Chloromethylated Polymeric Resin Beads," Analytica Chimica Acta, Vol. 584, No. 2, 2007, pp. 462-468. doi:10.1016/j.aca.2006.11.068 